\title{
Dynamic Mechanically Interlocked Dendrimers: Amplification in Dendritic Dynamic Combinatorial Libraries
}

\author{
Ken C.-F. Leung, Fabio Aricó, Stuart J. Cantrill, and J. Fraser Stoddart* \\ California NanoSystems Institute and Department of Chemistry and Biochemistry, University of \\ California, Los Angeles, 405 Hilgard Avenue, Los Angeles, California 90095-1569
}

Received July 27, 2006; Revised Manuscript Received September 15, 2006

\begin{abstract}
In the context of constructing nonclassical mechanically interlocked dendrimers by employing a convergent templation procedure, the "clipping" thermodynamic approach has been explored to introduce sterically bulky Fréchet-type dendrons with successive generations [G0] to [G3] onto a trivalent ammonium ion core using a seven-component self-assembly via imine bond formation. Four generations of mechanically interlocked dendrimers up to a molecular weight over 8800 Da were synthesized in a one-pot reaction by simply mixing the seven components together. The dendrimers form in excellent yield $(>90 \%)$. The mechanically interlocked core of the [G0]- [G2] dendrimers can be modified and transformed into kinetically stable dendrimers by reduction of the imine bonds with borane-tetrahydrofuran complex. Moreover, the dynamic nature of the thermodynamically controlled self-assembly process is employed to obtain three dynamic combinatorial libraries of dendrimers by the treatment of the dendrons $[\mathrm{G} 0]-[\mathrm{G} 3]$ with the complementary components in one pot. The inherent modularity of the overall process should allow for the rapid and straightforward access to many other analogues of mechanically interlocked systems for which either the branched core or the dendritic periphery can be modified to suit the needs of any potential application of these molecules.
\end{abstract}

\section{Introduction}

Recently, the advent ${ }^{1}$ of dynamic covalent chemistry (DCC) has granted to the synthetic chemists a means of constructing, with relatively high efficiencies, complex, mechanically interlocked compounds, such as catenanes, ${ }^{2}$ rotaxanes, ${ }^{3}$ molecular bundles, ${ }^{4}$ and even nanoscale Borromean rings, ${ }^{5}$ as a result of multicomponent, thermodynamically controlled self-assembly processes. The advantage of a thermodynamic process over a kinetic one is that it operates under reversible or quasi-reversible conditions in such a manner that undesired or competitive products can be recycled until the most energetically favored molecular structure(s) is (are) formed.

Up until recently, the approaches we were employing ${ }^{6,7}$ in attempts to construct mechanically interlocked dendrimers ${ }^{8,9}$ involved either (1) template-directed ${ }^{10}$ threading-followed-bystoppering and then, thereafter stopper exchange ${ }^{11}$ or (2) slippage. ${ }^{12}$ Both these methods were found to be severely lacking in the efficiencies required to render them in any way practical. Recently, however, we discovered ${ }^{13}$ the power of dynamic templating procedures for the all-but-quantitative construction (Figure 1) of mechanically interlocked dendrimers from generation zero [G0] to generation two [G2] in one pot using imine bond-forming reactions activated by $-\mathrm{CH}_{2} \mathrm{NH}_{2}{ }^{+}$ $\mathrm{CH}_{2}-$ centers. Furthermore, successful postsynthetic modifications of the dynamic mechanically interlocked dendrimers to fix the imine bonds by reduction were also shown to proceed more or less quantitatively. The rapid and high-yielding formation of mechanically interlocked dendrimers, in which the components can be mixed and matched according to need, offers considerable potential for the preparation of dendrimers with potential applications. ${ }^{14}$ In this article, the one-pot, highly efficient template-directed self-assembly of the [G0]-[G3] dynamic dendrimers with mechanically interlocked components,

* Corresponding author. Telephone: (+1)-310-206-7078. Fax: (+1)310-206-5621. E-mail: stoddart@chem.ucla.edu.

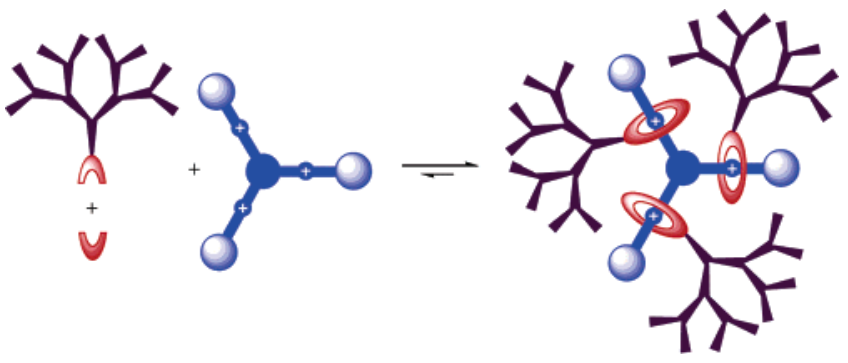

Figure 1. Graphical representation of the template-directed synthesis of mechanically interlocked dendrimers.

as well as the formation of dynamic combinatorial libraries ${ }^{15}$ by mixing the preformed dynamic dendrimers together, will be presented.

\section{Results and Discussion}

Synthesis by Templation and Self-Assembly. We have demonstrated (Scheme 1) the feasibility of constructing the [G0]-[G2] dynamic dendrimers $\mathbf{4 a}-\mathbf{c}-\mathrm{H}_{3} \cdot 3 \mathrm{PF}_{6}$ very efficiently by seven-component self-assembly processes in one-pot procedures which rely upon mixing 3 equiv of the dendritic dialdehydes $\mathbf{1 a}-\mathbf{c}$ and 3 equiv of the diamine $\mathbf{2}$ with 1 equiv of the trisammonium ion core $3-\mathrm{H}_{3} \cdot 3 \mathrm{PF}_{6}$ (total concentration $=35 \mathrm{mM}$ ) acting as a triple template. ${ }^{13}$ The driving force for this outcome is partly entropic since it represents the generation of the maximum number of discrete molecules commensurate with the operation of the principle of maximal site occupancy, ${ }^{16}$ i.e., the enthalpic component that gives the reaction an opportunity to seek out its thermodynamically most stable state. The molecular recognition associated with triple templation comes from the excellent match ${ }^{17,18}$ involving $\left[\mathrm{N}^{+}-\mathrm{H} \cdots \mathrm{O}\right]$ and $\left[\mathrm{N}^{+}-\mathrm{H} \cdots \mathrm{N}\right]$ hydrogen bonds and $[\mathrm{C}-\mathrm{H} \cdots \mathrm{O}]$ and $[\mathrm{C}-\mathrm{H} \cdots \mathrm{N}]$ interactions, augmented by some aromatic $\pi-\pi$ stacking interactions, that result from encircling the three dialkylammonium $\left(-\mathrm{CH}_{2} \mathrm{NH}_{2}{ }^{+} \mathrm{CH}_{2}-\right)$ centers with three [24]crown-8-like macrocycles. While the [G0]-[G3] dendritic dialdehydes $\mathbf{1 a}-\mathbf{d}$ 
Scheme 1. Seven-Component Self-Assemblies in One Pot Procedures of the [G0] $-[G 3]$ Dynamic Dendrimers $4 a-d_{-}-H_{3} \cdot 3 P F_{6}$

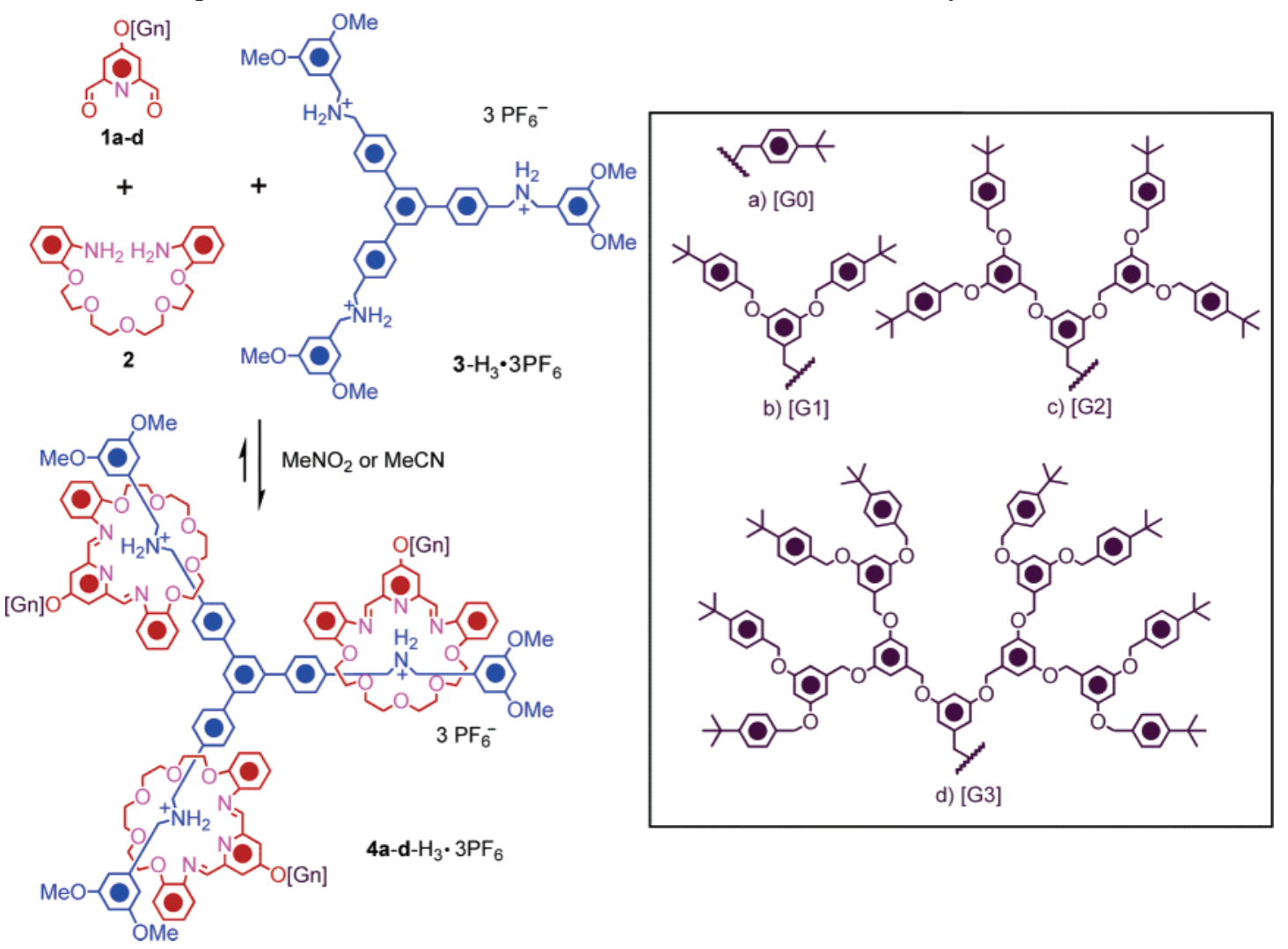

Scheme 2. Synthesis of the [G0]-[G3] Dendritic Dialdehydes 1a-d

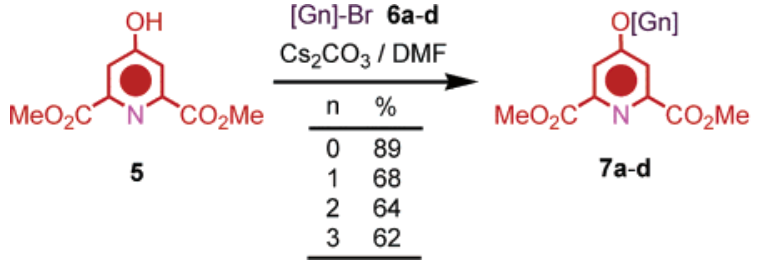

were synthesized (Scheme 2) from their corresponding bromides, ${ }^{19}$ the diamine $\mathbf{2}^{3 \mathrm{a}}$ and the trisammonium ion core $\mathbf{3}-\mathrm{H}_{3}$. $3 \mathrm{PF}_{6}{ }^{4}$ were prepared using literature procedures. 4-tertButylbenzyl bromide 6a ([G0]-Br) is commercially available, while the bromides $\mathbf{6 b}$ ([G1]-Br) and $\mathbf{6 c}$ ([G2]-Br) were synthesized using literature procedures. ${ }^{19}$ The [G3]-Br $6 \mathbf{d}$ was prepared from the known [G3]- $\mathrm{CO}_{2} \mathrm{Me} .{ }^{19}$ Subsequently, alkylation of 4-hydroxypyridine diester $\mathbf{5}^{20}$ with the [Gn]-Br $\mathbf{6 a}-\mathbf{d}$ in DMF in the presence of $\mathrm{Cs}_{2} \mathrm{CO}_{3}$ afforded the $[\mathrm{Gn}]$-dendritic diesters $\mathbf{7} \mathbf{a}-\mathbf{d}$ in $62-89 \%$ yield. Furthermore, reduction of 7a-d with $\mathrm{NaBH}_{4}$ in $\mathrm{MeOH} / \mathrm{THF}$ gave the $[\mathrm{Gn}]$-dendritic diols $\mathbf{8 a}-\mathbf{d}$ in $75-97 \%$ yield. Finally, the dendritic diols $\mathbf{8 a}-\mathbf{d}$ were oxidized to the desired [Gn]-dendritic dialdehydes $\mathbf{1 a}-\mathbf{d}$ in $41-$ $50 \%$ yield with $\mathrm{SeO}_{2}$ in 1,4-dioxane.

When either $\mathrm{CD}_{3} \mathrm{NO}_{2}$ or $\mathrm{CD}_{3} \mathrm{CN}$ was used as solvent, the self-assembly and templation processes proceed well in the concentration range between 35 and $140 \mathrm{mM}$. By way of an example, Figure 2 shows the partial ${ }^{1} \mathrm{H}$ NMR spectra $(500 \mathrm{MHz}$, $298 \mathrm{~K}$ ) of the [G2]-dynamic dendrimer $\mathbf{4} \mathbf{c}-\mathrm{H}_{3} \cdot 3 \mathrm{PF}_{6}$ obtained 20 min after the mixing of the appropriate components. For the formation of $4 \mathbf{c}-\mathrm{H}_{3} \cdot 3 \mathrm{PF}_{6}$ conducted in $\mathrm{CD}_{3} \mathrm{NO}_{2}$, it takes less than $15 \mathrm{~min}$ (total concentration $=35 \mathrm{mM}$ ) for the reaction to come to equilibrium, while in $\mathrm{CD}_{3} \mathrm{CN}$, it takes just over $20 \mathrm{~min}$ (total concentration $=35 \mathrm{mM}$ ), as indicated by the simplification of the resonances at $\delta 8.0-8.2 \mathrm{ppm}$ (Figure $2 \mathrm{~b}$ ) for the imine protons. The reason for this difference in the rates and extents

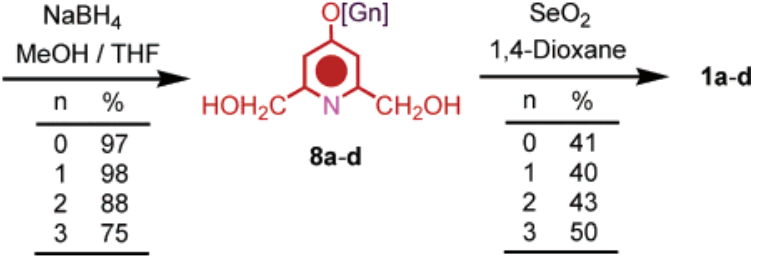

of reaction in $\mathrm{CD}_{3} \mathrm{NO}_{2}$ and $\mathrm{CD}_{3} \mathrm{CN}$ is believed to lie in the difference in polarities and in the fact that the $\mathrm{H}_{2} \mathrm{O}$ molecules, produced during the reaction of an aldehyde group with an amine function, are expelled immediately from the dendritic core in $\mathrm{CD}_{3} \mathrm{NO}_{2}$ solution, wherein $\mathrm{H}_{2} \mathrm{O}$ is partially immiscible, whereas they are miscible in the $\mathrm{CD}_{3} \mathrm{CN}$ solution. Clearly, the thermodynamic process does work more efficiently in dendritic core in $\mathrm{CD}_{3} \mathrm{NO}_{2}$ and so this solvent is the better one to use for this kind of condensation. Even although the molecular weight of the resulting [G3]-dynamic dendrimer $\mathbf{4} \mathbf{d}-\mathrm{H}_{3} \cdot 3 \mathrm{PF}_{6}$ exceeds $8800 \mathrm{Da}$, we can still witness the successful preparation of this dendrimer employing the one pot, self-assembly procedure in $\mathrm{CD}_{3} \mathrm{NO}_{2} / \mathrm{CDCl}_{3}(2: 1,35 \mathrm{mM})$.

Characterization. High resolution electrospray ionization mass spectrometry (HR-ESI-MS) proved to be a particularly useful technique for the characterization (Table 1) of the [G0][G3] dynamic dendrimers $\mathbf{4 a}-\mathbf{d}-\mathrm{H}_{3} \cdot 3 \mathrm{PF}_{6}$ in relation to both their purities and percentage yields. The errors between the calculated and experimental values are less than $0.01 \%$. Moreover, the observed isotopic distributions are consistent with the calculated values. The HR-ESI-MS of the [G3]-dynamic dendrimer 4d$\mathrm{H}_{3} \cdot 3 \mathrm{PF}_{6}$ reveals (Figure 3) a high-intensity signal at $\mathrm{m} / \mathrm{z}=$ 2798.4908, corresponding to the ion mass of $\left[\mathbf{4} \mathbf{c}-\mathrm{H}_{3}\right]^{3+}-\mathrm{i} . e$., the loss of all three $\mathrm{PF}_{6}{ }^{-}$counterions from the tricationic salt.

Although the synthetic protocol described in this paper represents a straightforward way of assembling mechanically 


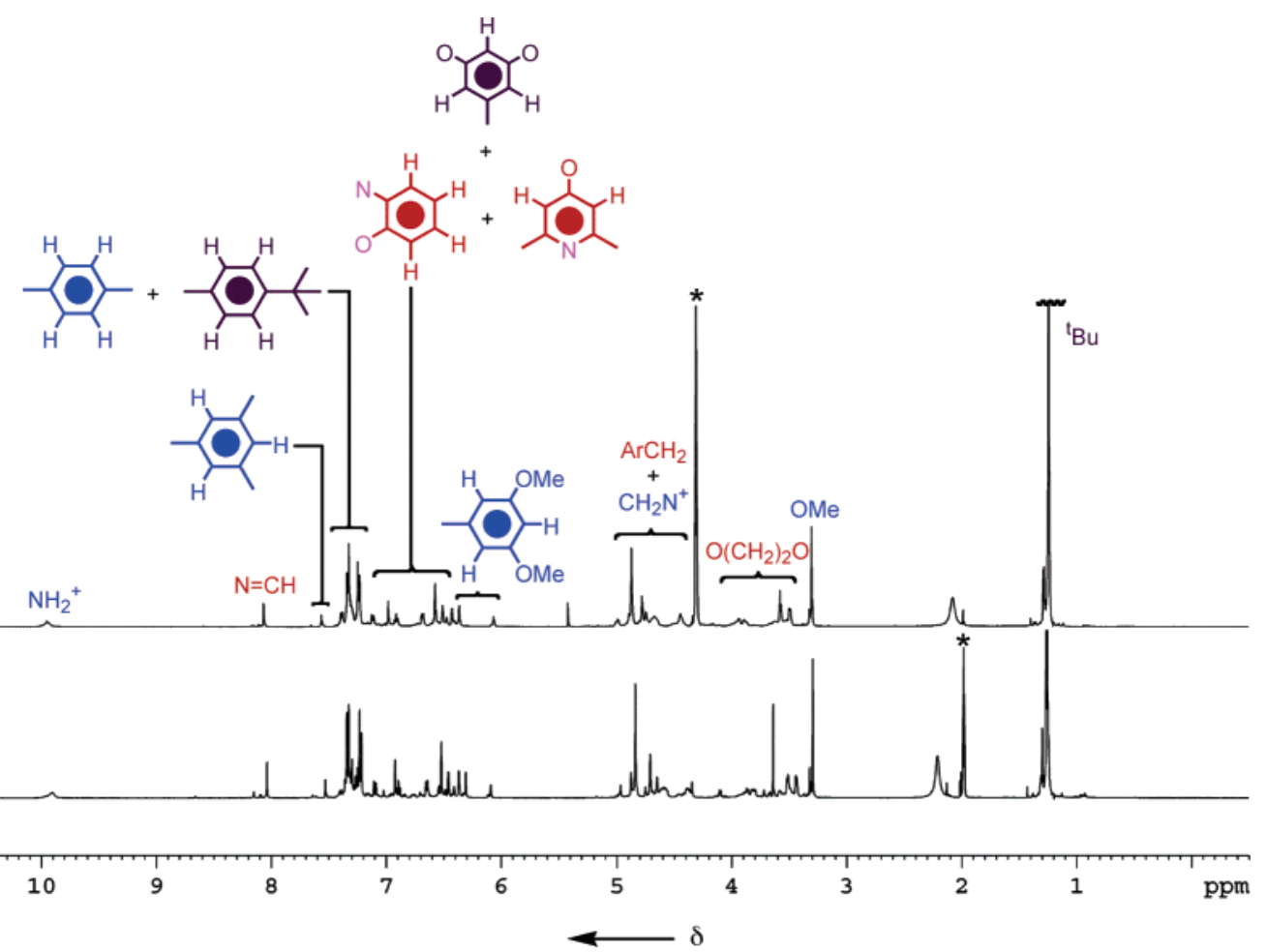

Figure 2. ${ }^{1} \mathrm{H}$ NMR spectra $(500 \mathrm{MHz}, 298 \mathrm{~K}, 35 \mathrm{mM})$ of the dynamic [G2]-dendrimer $4 \mathbf{c}-\mathrm{H}_{3} \cdot 3 \mathrm{PF}_{6}$ after 20 min of mixing of the appropriate components in (a) $\mathrm{CD}_{3} \mathrm{NO}_{2}$ and (b) $\mathrm{CD}_{3} \mathrm{CN}$ (* = solvent residue).

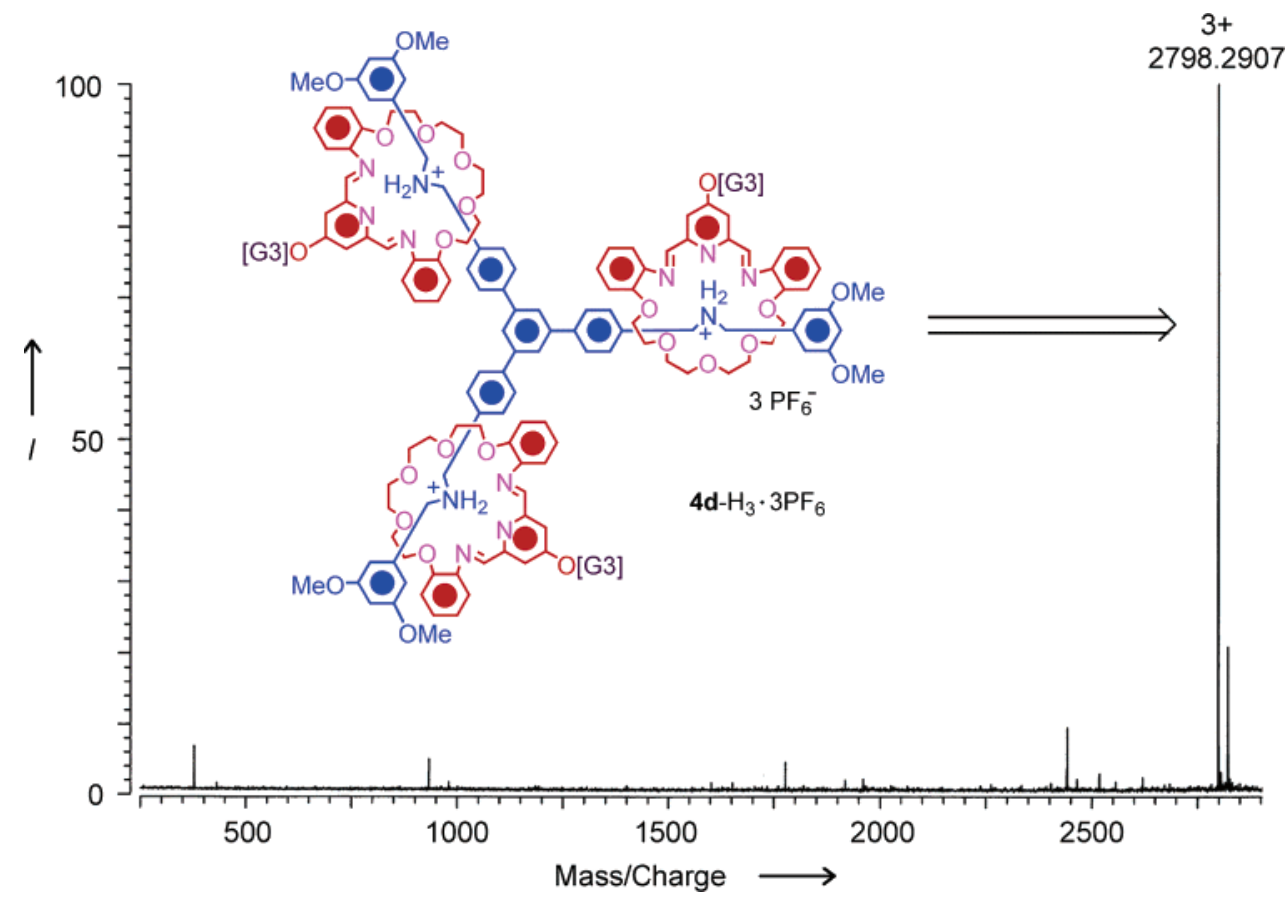

Figure 3. HR-ESI-MS analysis of the dynamic [G3]-dendrimer $\mathbf{4 d}-\mathrm{H}_{3} \cdot 3 \mathrm{PF}_{6}$.

Table 1. ESI-MS Data of the Dynamic [G0]-[G3] Dendrimers

\begin{tabular}{clrr}
\hline structure & molecular formula & calcd $m / z$ & found $m / z$ \\
\hline$\left[\mathbf{4 a}-\mathrm{H}_{3}\right]^{3+}$ & $\mathrm{C}_{168} \mathrm{H}_{189} \mathrm{~N}_{12} \mathrm{O}_{24}{ }^{3+}$ & 919.4646 & 919.4623 \\
{$\left[\mathbf{4 b}-\mathrm{H}_{3}\right]^{3+}$} & $\mathrm{C}_{222} \mathrm{H}_{249} \mathrm{~N}_{12} \mathrm{O}_{30}{ }^{3+}$ & 1187.6109 & 1187.6109 \\
{$\left[\mathbf{4 c}-\mathrm{H}_{3}\right]^{3+}$} & $\mathrm{C}_{330} \mathrm{H}_{369} \mathrm{~N}_{12} \mathrm{O}_{42}{ }^{3+}$ & 1723.9036 & 1723.9803 \\
{$\left[\mathbf{4 d}-\mathrm{H}_{3}\right]^{3+}$} & $\mathrm{C}_{546} \mathrm{H}_{609} \mathrm{~N}_{12} \mathrm{O}_{66}{ }^{3+}$ & 2796.4883 & 2796.5769
\end{tabular}

interlocked dendrimers from easily accessible starting materials, the dendrimers are dynamic and highly susceptible to break down because of the propensity to hydrolytic cleavage of their numerous imine bonds. Hence, it is imperative that we have a means of removing entirely this dynamic character by being able to reduce all six imine bonds in an efficient manner. Fortunately, we discovered recently ${ }^{3 \mathrm{f}, 13}$ that $\mathrm{BH}_{3} \cdot \mathrm{THF}$ is an effective reducing agent for these particular imine bonds and so we experimented with it to discover that it is an excellent reducing agent for the dynamic dendrimers in question, giving high yields of the expected products without jeopardizing the integrities of the dendrimers (Scheme 3 ). Thus, when the fixing of the $[\mathrm{G} 0]-[\mathrm{G} 2]$ dynamic dendrimers $\mathbf{4 a}-\mathbf{c}-\mathrm{H}_{3} \cdot 3 \mathrm{PF}_{6}$ was carried out using $\mathrm{BH}_{3} \cdot$ THF (two equiv per imine bond), followed by the treatment with $\mathrm{NaOH} / \mathrm{H}_{2} \mathrm{O}(2 \mathrm{M})$, complete reduction of all the imine bonds to their corresponding amino 
Scheme 3. Fixing of the Dynamic [G0]-[G3] Dendrimers 4a-d- $\mathrm{H}_{3} \cdot 3 \mathrm{PF}_{6}$ To Give the Neutral $[\mathrm{G} 0]-[\mathrm{G} 3]$ Dendrimers 9a-d

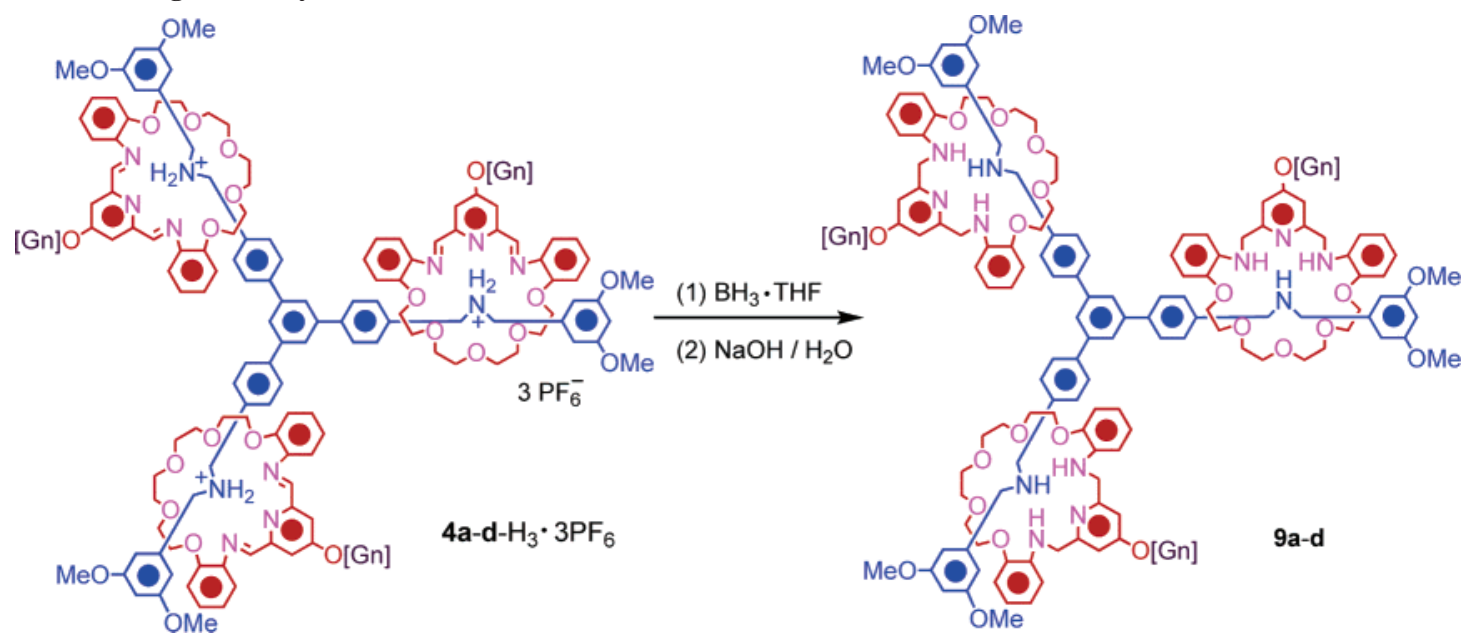

functions was achieved, affording the kinetically stable neutral [G0]-[G2] dendrimers $9 \mathbf{a}-\mathbf{c}$ after only $6 \mathrm{~h}$ without any need for further purification by chromatography. The remarkable efficiency of this fixing procedure was confirmed by both ${ }^{1} \mathrm{H}$ NMR spectroscopy and ESI-MS on the crude products from the reductions. We discovered, however, that the efficiency of this fixing procedure has its limitations. In the case of the dynamic [G3]-dendrimer $\mathbf{4} \mathbf{d}-\mathrm{H}_{3} \cdot 3 \mathrm{PF}_{6}$, the matrix-assisted laser desorption/ionization-time-of-flight-mass spectrometry (MALDITOF-MS) revealed (Figure 4) that the attempted reduction did not proceed to completion to give the fully reduced neutral dendrimer 9d: instead, the reaction produced a mixture of compounds, including 9d plus degraded neutral dendrimers with only two and one dendrons linked noncovalently to the trivalent core in 3, 32, and $100 \%$ relative intensities, respectively, from the MS spectrum. The reason for this dramatic drop in the efficiency of the fixing procedure to obtain neutral [G3] dendrimer $9 \mathrm{~d}$ is presumably associated with the increased steric hindrance imposed by the larger [G3] dendrons on the trivalent core, diminishing the accessibility of the imine bonds to the

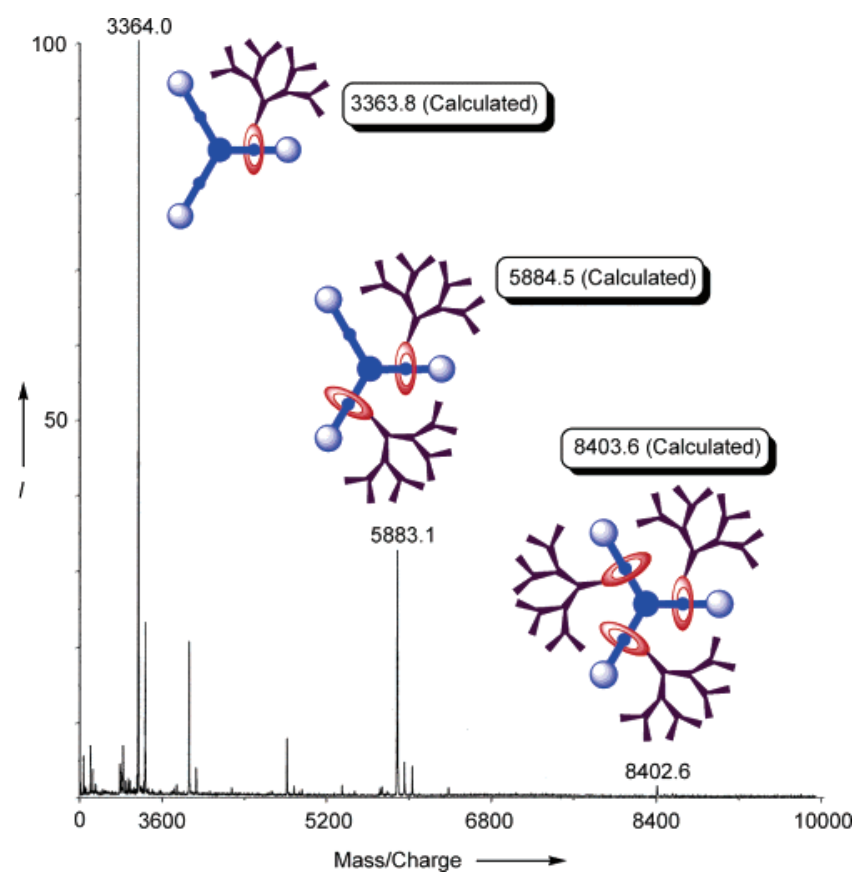

Figure 4. MALDI-TOF-MS of the mixture after the fixation/ reduction of dynamic [G3]-dendrimer $\mathbf{4} \mathbf{d}-\mathrm{H}_{3} \cdot 3 \mathrm{PF}_{6}$, indicating the formation of a mixture of degraded [G3]-dendrimers. reducing agent so that a lot of them remain intact. As a consequence, work-up with the excess of aqueous $2 \mathrm{M} \mathrm{NaOH}$ solution results in the hydrolysis of the remaining imine bonds, leading to the detachment of a number of the dendrons.

Formation of Dynamic Combinatorial Libraries. On account of the reversibility of the imine bond formation, we have examined the consequences of mixing dynamic dendrimers of different generations in one pot to obtain three dynamic combinatorial libraries of mechanically interlocked dendrimer via competitive self-assembly. To begin with, after mixing the equimolar amount of the preformed dynamic [G0] and [G2] dendrimers $\mathbf{4 a}-\mathrm{H}_{3} \cdot 3 \mathrm{PF}_{6}$ and $\mathbf{4 c}-\mathrm{H}_{3} \cdot 3 \mathrm{PF}_{6}(\mathrm{MeCN}, 298 \mathrm{~K}$, total concentration $=70 \mathrm{mM}$ ) in the presence of catalytic amount of $\mathrm{HPF}_{6}$ solution for $12 \mathrm{~h}$, the constitution of the dynamic library formed was characterized by ESI-MS. ${ }^{21}$ Somewhat to our surprise, the mass spectrum of the dynamic mixture (Figure 5) shows strong and sharp signals. The signals at $\mathrm{m} / \mathrm{z}=919.8$ and 1725.5 Da correspond to the dynamic [G0]-dendrimer 4a$\mathrm{H}_{3} \cdot 3 \mathrm{PF}_{6}$ and [G2] dendrimer $\mathbf{4} \mathbf{c}-\mathrm{H}_{3} \cdot 3 \mathrm{PF}_{6}$, respectively. The signals at $m / z=1188.5$ and $1456.8 \mathrm{Da}$ represent the newly formed, mixed-dendron dynamic dendrimers with [G0]/[G0]/ [G2] and [G0]/[G2]/[G2] dendrons at their peripheries. The relative intensities of the signal are summarized in Figure 6a. Moreover, under the thermodynamic, dendron-exchanging process, no other cyclic or linear oligomers/polymers were detected by ESI-MS. The dendron exchange process undoubtedly involves the water molecules in the acidic condition present in the preformed dynamic [G0] and [G2] dendrimers $\left(\mathbf{4 a}-\mathrm{H}_{3} \cdot 3 \mathrm{PF}_{6}\right.$ and $\mathbf{4} \mathbf{c}-\mathrm{H}_{3} \cdot 3 \mathrm{PF}_{6}$ ), responsible for the forming and breaking of the dynamic imine bonds.

The second dendritic dynamic combinatorial library was formed by mixing the diamine 2 ( 3 equiv), the triammonium core $3-\mathrm{H}_{3} \cdot 3 \mathrm{PF}_{6}$ (1 equiv) and 3 equiv each of the [G0]-, [G1]and [G2]-dendritic dialdehyde $\mathbf{1 a}-\mathbf{d}$ in one-pot $\left(\mathrm{MeNO}_{2}, 298\right.$ $\mathrm{K}$, total concentration $=65 \mathrm{mM}$ ) in order to give 10 different dynamic dendrimers. In this case, the dendritic dialdehydes are in excess relative to the diamine $\mathbf{2}$ and the triammonium core $3-\mathrm{H}_{3} \cdot 3 \mathrm{PF}_{6}$. The ESI-MS results (Figure $6 \mathrm{~b}$ ) revealed the absence of the $[\mathrm{G} 2] /[\mathrm{G} 2] /[\mathrm{G} 2]\left(\mathbf{4 c}-\mathrm{H}_{3} \cdot 3 \mathrm{PF}_{6}\right)$ dynamic dendrimer in the mixture. Moreover, the MS signal of $[\mathrm{G} 0] /[\mathrm{G} 0] /[\mathrm{G} 2]$ dynamic dendrimer is overlapped with the signal of $[\mathrm{G} 1] /[\mathrm{G} 1] /[\mathrm{G} 1]{ }^{22}$ On the other hand, the third dendritic dynamic combinatorial library was formed by mixing equimolar amount of the preformed [G0]-, [G1]-, [G2]- and [G3]-dynamic dendrimers $\mathbf{4 a}-\mathbf{d}-\mathrm{H}_{3} \cdot 3 \mathrm{PF}_{6}$ together in one pot $\left(2: 1 \mathrm{MeCN} / \mathrm{CH}_{2} \mathrm{Cl}_{2}, 298 \mathrm{~K}\right.$, 


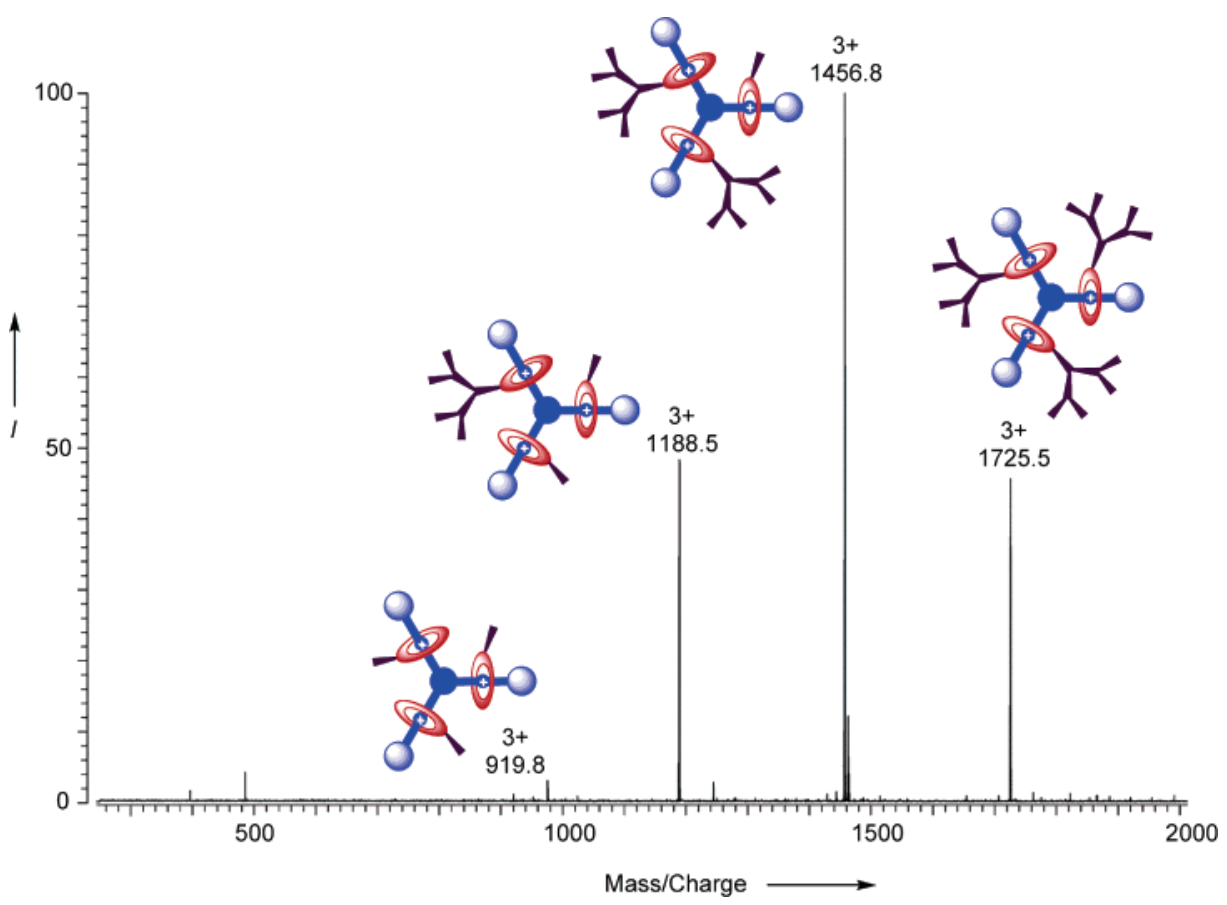

Figure 5. ESI-MS result of the $1: 1$ mixture of dynamic [G0]-dendrimer $4 \mathrm{a}-\mathrm{H}_{3} \cdot 3 \mathrm{PF}_{6}$ and dynamic [G2]-dendrimer $4 \mathrm{c}-\mathrm{H}_{3} \cdot 3 \mathrm{PF}_{6}$, indicating the newly formed, mixed-dendron dynamic dendrimers in $\mathrm{MeCN}$.

(a)

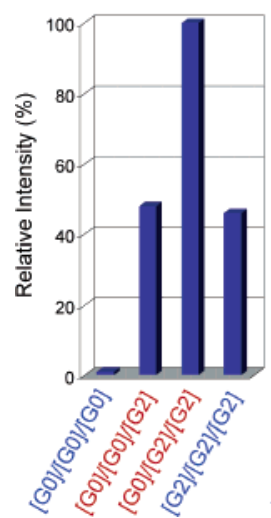

(b)

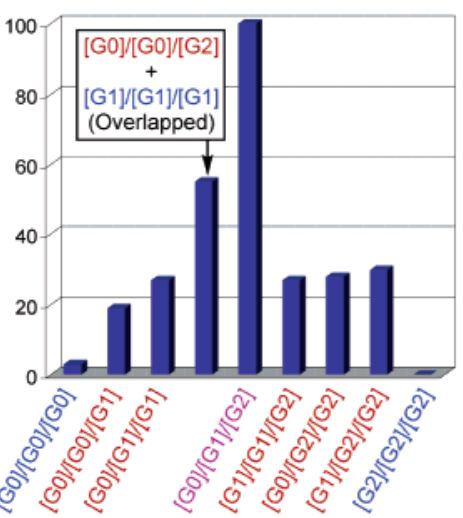

(c)

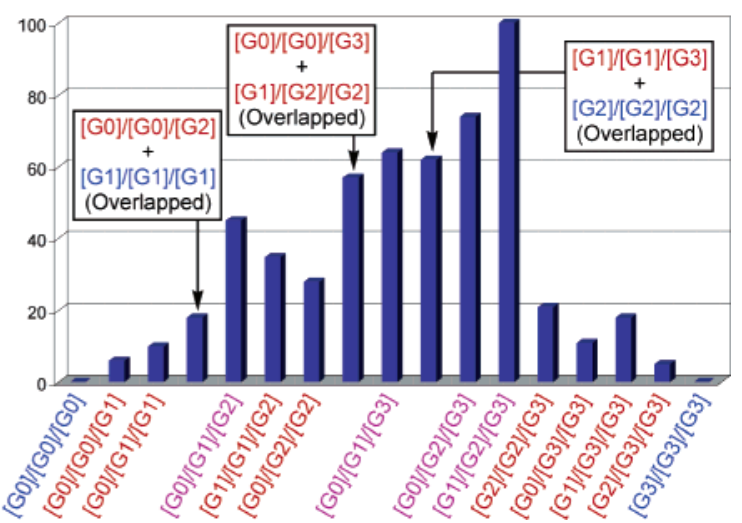

Figure 6. ESI-MS results of dendritic dynamic combinatorial library formed by mixing (a) preformed [G0]- [G2]-dynamic dendrimers $\left(4 \mathbf{a}^{-} \mathrm{H}_{3}\right.$. $3 \mathrm{PF}_{6}$ and $\mathbf{4} \mathbf{c}-\mathrm{H}_{3} \cdot 3 \mathrm{PF}_{6}$ ), (b) 3 equiv of $\mathbf{2}, 1$ equiv of $\mathbf{3}-\mathrm{H}_{3} \cdot 3 \mathrm{PF}_{6}$, and 3 equiv each of [G0]-[G2] dendritic dialdehyde $\mathbf{1 a}-\mathbf{c}$ and (c) preformed [G0]-[G3] dynamic dendrimers $\mathbf{4 a}-\mathbf{d}-\mathrm{H}_{3} \cdot 3 \mathrm{PF}_{6}$ in one pot (the $[\mathrm{Gx}] /[\mathrm{Gx}] /[\mathrm{Gx}]$-type dynamic dendrimers are shown in blue; the $[\mathrm{Gx}] /[\mathrm{Gx}] /[\mathrm{Gy}]-$ type dynamic dendrimers are shown in red; and the $[\mathrm{Gx}] /[\mathrm{Gy}] /[\mathrm{Gz}]$-type dynamic dendrimers are shown in purple).

total concentration $=70 \mathrm{mM}$ ) in the presence of catalytic amount of $\mathrm{HPF}_{6}$ solution for 2 days. The resulting solution was subjected to ESI-MS analysis (Figure 6c). One should expect that the mixing of the four dynamic dendrimers should give rise into 20 different dynamic dendrimers within three categories - $[\mathrm{Gx}] /[\mathrm{Gx}] /[\mathrm{Gx}]-,[\mathrm{Gx}] /[\mathrm{Gx}] /[\mathrm{Gy}]$-and $[\mathrm{Gx}] /[\mathrm{Gy}] /[\mathrm{Gz}]$-type dendrimers, via the dendron exchanging process. However, the ESI-MS results revealed that the $[\mathrm{G} 0] /[\mathrm{G} 0] /[\mathrm{G} 0]\left(\mathbf{4 a}-\mathrm{H}_{3} \cdot 3 \mathrm{PF}_{6}\right)$ and $[\mathrm{G} 3] /[\mathrm{G} 3] /[\mathrm{G} 3]\left(\mathbf{4} \mathbf{d}-\mathrm{H}_{3} \cdot 3 \mathrm{PF}_{6}\right)$ dynamic dendrimers are not detected. The MS signals of $[\mathrm{G} 0] /[\mathrm{G} 0] /[\mathrm{G} 2],[\mathrm{G} 0] /[\mathrm{G} 0] /[\mathrm{G} 3]$ and $[\mathrm{G} 1] /[\mathrm{G} 1] /[\mathrm{G} 3]$ dynamic dendrimers are overlapped with the signals of $[\mathrm{G} 1] /[\mathrm{G} 1] /[\mathrm{G} 1],[\mathrm{G} 1] /[\mathrm{G} 2] /[\mathrm{G} 2]$ and $[\mathrm{G} 2] /[\mathrm{G} 2] /$ $[\mathrm{G} 2]$ dynamic dendrimers, respectively. ${ }^{22}$

Statistically, the ratio of $[\mathrm{Gx}] /[\mathrm{Gx}] /[\mathrm{Gx}]:[\mathrm{Gx}] /[\mathrm{Gx}] /[\mathrm{Gy}]:[\mathrm{Gx}] /$ $[\mathrm{Gy}] /[\mathrm{Gz}]$ dynamic dendrimers in the mixture should be 1:3:6 despite other structural or electronic effects. Comparatively, a general trend as indicated by the relative MS intensities from the three dendritic dynamic combinatorial libraries (Figure 6) can be observed: In a dynamic library, the $[\mathrm{Gx}] /[\mathrm{Gy}] / \mathrm{Gz}]$-type dynamic dendrimer(s) ([G0]/[G1]/[G2], [G0]/[G1]/[G3], [G0]/
$[\mathrm{G} 2] /[\mathrm{G} 3]$ and $[\mathrm{G} 1] /[\mathrm{G} 2] /[\mathrm{G} 3]$ dynamic dendrimers) is (are) amplified in the competitive equilibrium mixture. For the second dendritic dynamic combinatorial library, the statistical effect is dominant. However, other effects instead of the statistical effect should also be accounted to explain the observed relative MS intensities in the dynamic libraries. First, the steric (backfolding) effect of the dendrons with increasing steric bulk should inhibit the formation of self-assembling dynamic dendrimers, which means that the dynamic dendrimers having higher molecular weights/dendron generations (e.g., [G3]/[G3]/[G3] dendrimer) are less stable, comparatively, in the competitive mixture. The second effect is the hydrophobicity (or polarity) in the dendritic environment. For dynamic dendrimers having lower dendron generations, the permeability of water molecules from the periphery to the core to hydrolyze the imine bonds, is enhanced because of their low hydrophobicity (or high polarity). The stabilities of low molecular weight/generation dynamic dendrimers (e.g., [G0]/[G0]/[G0] dendrimer) decrease comparatively in the competitive mixture. For the first dynamic library (Figure $6 \mathrm{a})$, the $[\mathrm{G} 0] /[\mathrm{G} 2] /[\mathrm{G} 2]$ dynamic dendrimer was amplified while 
for the second dynamic library, the [G0]/[G1]/[G2] dynamic dendrimer was amplified (Figure 6b). Fot the third dynamic libraries, statistically, the $[\mathrm{G} 0] /[\mathrm{G} 1] /[\mathrm{G} 2],[\mathrm{G} 0] /[\mathrm{G} 1] /[\mathrm{G} 3],[\mathrm{G} 0] /$ [G2]/[G3] and [G1]/[G2]/[G3] dynamic dendrimers should have the same relative intensity. However, for these four specific $[\mathrm{Gx}] /[\mathrm{Gy}] /[\mathrm{Gz}]$-type dynamic dendrimers, the MS intensity increases as the size of the dendrimer increase (the [G1]/[G2]/ [G3] dynamic dendrimer has the highest MS intensity). Therefore, in this case, the hydrophobic effect (or polarity) plays a more important role than the steric effect to govern the relative stabilities of dynamic dendrimers in the competitive mixture. Additionally, this conclusion can also be supported by the unexpected drop in relative MS intensities of the dynamic dendrimers bearing [G0]-dendron(s) in all three dynamic libraries.

Generally, this protocol offers the mix and match of dendrons with different generations to a central tritopic ammonium core to afford new types of dendrimers, which cannot be obtained at all by conventional synthetic methods, or if they can, the task will be too demanding on time and resources. For a small dendritic dynamic library, eventually, the dynamic dendrimers with vastly different in molecular weights formed in the library can be reduced to their corresponding kinetically stable dendrimers by borane reductions and can be further separated and isolated by preparative gel permeation chromatographic methods.

\section{Conclusion}

The utility of dynamic covalent chemistry in the thermodynamically controlled, modular synthesis of a series of mechanically interlocked dendrimers from generation zero to three has been assessed. Starting with the simple mixing of precursor components, this approach has been demonstrated to be an effective, high yielding self-assembly process. The sevencomponent self-assembly proceeds well in nitromethane and acetonitrile. Postsynthetic fixing (by imine reduction) can also be achieved for all generation zero to generation two dynamic dendrimers, affording the corresponding kinetically stable interlocked dendrimers in high yields without any further purification steps. However, on account of the steric hindrance associated with the [G3] dendron, the attempted reduction of the [G3]-dynamic dendrimer yields a mixture of degraded dendrimers. Moreover, dynamic combinatorial libraries of mechanically interlocked dendrimers can be created by mixing appropriate amounts of the preformed dynamic dendrimers or their components. The mixed-dendron dynamic dendrimers present in the libraries would not be easy to obtain by conventional synthesis. In principle, dendrons bearing different functional moieties, different generations can be mixed, matched, and self-assembled into novel functional dendritic compounds by an approach that is both rapid and efficient.

\section{Experimental Section}

General Methods. Lithium aluminum hydride (95\%), tetrabromomethane (99\%), triphenylphosphine (99\%), cesium carbonate $(99.95 \%)$, sodium borohydride $(99 \%)$, hydrogen hexafluorophosphate (60 wt \% in water), $N, N$-dimethylformamide (DMF, anhydrous, $99.8 \%$ ), methanol (anhydrous, 99.8\%), tetrahydrofuran (THF, anhydrous $99.9 \%$ ), nitromethane ( $\geq 95 \%)$, acetonitrile (anhydrous, $99.8 \%$ ), and borane-THF complex solution (1.8 M in THF) were purchased from Aldrich and used without further purification. Deuterated nitromethane (99\% D) and acetonitrile (99.8\% D) were purchased from Cambridge Isotope Laboratory and dried with molecular sieves ( $4 \AA$ ) prior to use. All reactions were carried out under an argon atmosphere. Thin-layer chromatography was performed on silica gel sheet $60 \mathrm{~F}_{254}$ (Merck). Column chromatography was performed on silica gel 60F (Merck 9385, 0.040-0.063 $\mathrm{mm})$. All NMR spectra were recorded on a Bruker Advance 500 $\left({ }^{1} \mathrm{H}\right.$ at $500 \mathrm{MHz}$ and ${ }^{13} \mathrm{C}$ at $\left.126 \mathrm{MHz}\right)$ spectrometer and $\mathrm{CDCl}_{3}$ was used as the solvent unless otherwise stated. Chemical shifts are reported in parts per million (ppm) downfield from the signal for $\mathrm{Me}_{4} \mathrm{Si}$ used as the internal standard. ESI mass spectra were recorded either on an IonSpec Fourier transform mass spectrometer or a VG ProSpec triple focusing mass spectrometer with $\mathrm{MeCN}$ as the mobile phase. High-resolution MALDI mass spectra were recorded on an IonSpec Fourier transform mass spectrometer with $\alpha$-cyano-4-hydroxycinnamic acid as the calibration matrix. The reported molecular mass $(\mathrm{m} / \mathrm{z})$ values are for the most abundant monoisotopic masses.

[G3]-Dendritic Bromide 6d. $\mathrm{LiAlH}_{4}(0.12 \mathrm{~g}, 3.1 \mathrm{mmol})$ was added portionwise to the solution of [G3] $-\mathrm{CO}_{2} \mathrm{Me}^{19}$ (4.3 g, 2.1 mmol) in THF $(20 \mathrm{~mL})$ at $0{ }^{\circ} \mathrm{C}$. The slurry was stirred for $2 \mathrm{~h}$ at $25^{\circ} \mathrm{C}$, and subsequently quenched by dropwise addition of $\mathrm{H}_{2} \mathrm{O}$ $(1 \mathrm{~mL})$ at $0{ }^{\circ} \mathrm{C}$ and then with $1 \mathrm{M} \mathrm{HCl}(30 \mathrm{~mL})$. The resulting mixture was extracted with EtOAc $(2 \times 20 \mathrm{~mL})$. The combined extracts were washed with brine, dried $\left(\mathrm{MgSO}_{4}\right)$ and filtered. The collected filtrate was evaporated to dryness under reduced pressure. The residue was then redissolved in THF $(15 \mathrm{~mL})$, followed by the successive addition of $\mathrm{CBr}_{4}(1.0 \mathrm{~g}, 3.2 \mathrm{mmol})$ and $\mathrm{PPh}_{3}(1.1 \mathrm{~g}$, $4.2 \mathrm{mmol})$ at $25{ }^{\circ} \mathrm{C}$. After stirring for $2 \mathrm{~h}$, anhydrous $\mathrm{Et}_{2} \mathrm{O}(10$ $\mathrm{mL}$ ) was added to the mixture. Then, the mixture was filtered through a short pad of Celite. The collected filtrate was concentrated under reduced pressure, and the residue was purified by column chromatography (silica gel, eluent: hexanes gradient to hexane/ EtOAc $=5: 1)$ to afford the bromide $\mathbf{6 d}(3.3 \mathrm{~g}, 75 \%$ yield $)$ as a colorless glassy solid. ${ }^{1} \mathrm{H}$ NMR: $\delta=1.31(\mathrm{~s}, 72 \mathrm{H}), 4.37(\mathrm{~s}, 2 \mathrm{H})$, $4.96(\mathrm{~s}, 28 \mathrm{H}), 6.50-6.70(\mathrm{~m}, 21 \mathrm{H}), 7.34(\mathrm{~d}, J=8.3 \mathrm{~Hz}, 16 \mathrm{H})$, $7.39(\mathrm{~d}, J=8.3 \mathrm{~Hz}, 16 \mathrm{H}) .{ }^{13} \mathrm{C}$ NMR: $\delta=31.3,33.7,34.6,69.9$, 70.0, 101.5, 102.2, 106.2, 108.1, 125.5, 127.5, 133.6, 138.9, 139.7, 151.06, 159.9, 161.2. MS (HR-ESI): calcd for $\mathrm{C}_{137} \mathrm{H}_{156} \mathrm{BrO}_{14} \mathrm{~m} / \mathrm{z}$ $=2104.0678$; found $\mathrm{m} / \mathrm{z}=2104.0673\left[(\mathrm{M}+\mathrm{H})^{+}, 100 \%\right]$.

General Procedure for [G0]-[G3] Dendritic Diesters 7a-d. A mixture of the 4-hydroxypyridine derivative $\mathbf{5}^{20}$ (1.0 equiv), [Gn]$\mathrm{Br} \mathbf{6 a}-\mathbf{d}$ (1.1 equiv) and $\mathrm{Cs}_{2} \mathrm{CO}_{3}$ (1.5 equiv) in $\mathrm{DMF}(2 \mathrm{~mL} / \mathrm{mM})$ was stirred for $2 \mathrm{~h}$ at $60^{\circ} \mathrm{C}$. The reaction mixture was then quenched with $\mathrm{H}_{2} \mathrm{O}$, and extracted twice with EtOAc. The organic phase extracts were combined and washed with brine, dried $\left(\mathrm{MgSO}_{4}\right)$, and filtered. The filtrate was evaporated under reduced pressure, and the residue was purified by column chromatography on silica gel with hexane/EtOAc (2:1 gradient to 3:2) as the eluent to afford the $[\mathrm{G} n]$-dendritic diesters $7 \mathbf{a}-\mathbf{d}$.

[G0]-Dendritic Diester 7a. Starting from compound 5 (4.0 g, $19 \mathrm{mmol}),[\mathrm{G0}]-\mathrm{Br} \mathbf{6 a}(90 \%, 4.7 \mathrm{~mL}, 23 \mathrm{mmol})$, and $\mathrm{Cs}_{2} \mathrm{CO}_{3}(12.4$ $\mathrm{g}, 38 \mathrm{mmol})$ in DMF $(70 \mathrm{~mL})$, the diester $7 \mathrm{a}(6.0 \mathrm{~g}, 89 \%$ yield $)$ was obtained as a white solid. Mp: $92.4-95.6{ }^{\circ} \mathrm{C} .{ }^{1} \mathrm{H}$ NMR: $\delta=$ $1.33(\mathrm{~s}, 9 \mathrm{H}), 4.01(\mathrm{~s}, 6 \mathrm{H}), 5.19(\mathrm{~s}, 2 \mathrm{H}), 7.37$ (d, $J=8.3 \mathrm{~Hz}, 2$ $\mathrm{H}), 7.44(\mathrm{~d}, J=8.3 \mathrm{~Hz}, 2 \mathrm{H}), 7.89$ (s, $2 \mathrm{H}) .{ }^{13} \mathrm{C}$ NMR: $\delta=31.3$, 34.7, 53.3, 70.8, 114.8, 125.8, 127.7, 131.6, 149.8, 152.0, 165.2, 166.8. MS (HR-MALDI): calcd for $\mathrm{C}_{20} \mathrm{H}_{23} \mathrm{NO}_{5} \mathrm{Na} \mathrm{m} / \mathrm{z}=380.1474$; found $\mathrm{m} / \mathrm{z}=380.1456\left[(\mathrm{M}+\mathrm{Na})^{+}, 100 \%\right]$.

[G1]-Dendritic Diester 7b. Starting from compound 5 (1.0 g, $4.7 \mathrm{mmol}),[\mathrm{G} 1]-\mathrm{Br} 6 \mathbf{6}(2.8 \mathrm{~g}, 5.7 \mathrm{mmol})$, and $\mathrm{Cs}_{2} \mathrm{CO}_{3}(2.1 \mathrm{~g}, 6.6$ $\mathrm{mmol})$ in DMF $(25 \mathrm{~mL})$, the diester $7 \mathbf{b}(2.0 \mathrm{~g}, 68 \%$ yield $)$ was obtained as a white solid. Mp: $139.8-142.6{ }^{\circ} \mathrm{C} .{ }^{1} \mathrm{H}$ NMR: $\delta=$ $1.33(\mathrm{~s}, 18 \mathrm{H}), 4.01(\mathrm{~s}, 6 \mathrm{H}), 5.00(\mathrm{~s}, 4 \mathrm{H}), 5.16(\mathrm{~s}, 2 \mathrm{H}), 6.62(\mathrm{t}$, $J=2.8 \mathrm{~Hz}, 1 \mathrm{H}), 6.67(\mathrm{~d}, J=2.8 \mathrm{~Hz}, 2 \mathrm{H}), 7.36(\mathrm{~d}, J=8.3 \mathrm{~Hz}$, $4 \mathrm{H}), 7.42(\mathrm{~d}, J=8.3 \mathrm{~Hz}, 4 \mathrm{H}), 7.89$ (s, $2 \mathrm{H}) .{ }^{13} \mathrm{C}$ NMR: $\delta=$ 31.3, 34.6, 53.2, 70.1, 70.6, 102.0, 106.4, 114.8, 125.6, 127.5, 133.5, $136.8,149.8,151.2,160.4,165.1,166.6 . \mathrm{MS}$ (HR-MALDI): calcd for $\mathrm{C}_{38} \mathrm{H}_{43} \mathrm{NO}_{7} \mathrm{Na} m / z=648.2937$; found $\mathrm{m} / z=648.2902[(\mathrm{M}+$ $\left.\mathrm{Na})^{+}, 100 \%\right]$.

[G2]-Dendritic Diester 7c. Starting from compound 5 (0.17 g, $0.81 \mathrm{mmol}),[\mathrm{G} 2]-\mathrm{Br} \mathbf{6 c}(1.0 \mathrm{~g}, 0.97 \mathrm{mmol})$, and $\mathrm{Cs}_{2} \mathrm{CO}_{3}(0.53 \mathrm{~g}$, $1.6 \mathrm{mmol})$ in DMF $(10 \mathrm{~mL})$, the diester $7 \mathrm{c}(0.6 \mathrm{~g}, 64 \%$ yield $)$ was obtained as a colorless glassy solid. ${ }^{1} \mathrm{H}$ NMR: $\delta=1.33(\mathrm{~s}, 36 \mathrm{H})$, 4.00 (s, $6 \mathrm{H}), 4.99$ (s, $12 \mathrm{H}), 5.16(\mathrm{~s}, 2 \mathrm{H}), 6.59$ (t, $J=2.8 \mathrm{~Hz}, 2$ 
$\mathrm{H}), 6.60(\mathrm{t}, J=2.8 \mathrm{~Hz}, 1 \mathrm{H}), 6.63(\mathrm{~d}, J=2.8 \mathrm{~Hz}, 2 \mathrm{H}), 6.68(\mathrm{~d}$, $J=2.8 \mathrm{~Hz}, 4 \mathrm{H}), 7.35(\mathrm{~d}, J=8.3 \mathrm{~Hz}, 8 \mathrm{H}), 7.41(\mathrm{~d}, J=8.3 \mathrm{~Hz}$, $8 \mathrm{H}), 7.89(\mathrm{~s}, 2 \mathrm{H}) .{ }^{13} \mathrm{C}$ NMR: $\delta=31.2,34.5,53.2,69.9,70.0$, $70.5,101.4,102.0,106.2,106.4,114.7,125.4,127.5,133.6,136.8$, $149.8,151.0,160.18,160.21,165.0,166.5$. MS (HR-MALDI): calcd for $\mathrm{C}_{74} \mathrm{H}_{83} \mathrm{NO}_{11} \mathrm{Na} \mathrm{m} / \mathrm{z}=1184.5864$; found $\mathrm{m} / \mathrm{z}=1184.5885$ $\left[(\mathrm{M}+\mathrm{Na})^{+}, 100 \%\right]$.

[G3]-Dendritic Diester 7d. Starting from compound 5 (0.14 g, $0.67 \mathrm{mmol}),[\mathrm{G} 3]-\mathrm{Br}$ 6d $(1.5 \mathrm{~g}, 0.74 \mathrm{mmol})$, and $\mathrm{Cs}_{2} \mathrm{CO}_{3}(0.43 \mathrm{~g}$, $1.3 \mathrm{mmol})$ in DMF (8 mL), the diester $7 \mathbf{d}(0.92 \mathrm{~g}, 62 \%$ yield $)$ was obtained as a colorless glassy solid. ${ }^{1} \mathrm{H}$ NMR: $\delta=1.33(\mathrm{~s}, 72 \mathrm{H})$, $4.00(\mathrm{~s}, 6 \mathrm{H}), 5.01(\mathrm{~s}, 28 \mathrm{H}), 5.13(\mathrm{~s}, 2 \mathrm{H}), 6.55-6.72(\mathrm{~m}, 21 \mathrm{H})$, $7.36(\mathrm{~d}, J=8.3 \mathrm{~Hz}, 16 \mathrm{H}), 7.41(\mathrm{~d}, J=8.3 \mathrm{~Hz}, 16 \mathrm{H}), 7.89(\mathrm{~s}, 2$ H). ${ }^{13} \mathrm{C}$ NMR: $\delta=31.3,34.5,53.2,69.9,70.0,101.4,101.5,101.9$, 106.2, 106.3, 106.5, 114.7, 125.4, 127.5, 133.6, 138.9, 139.0, 149.8, 151.0, 160.0, 160.2, 165.0, 166.5. MS (HR-MALDI): calcd for $\mathrm{C}_{146} \mathrm{H}_{163} \mathrm{NO}_{19} \mathrm{Na} \mathrm{m} / \mathrm{z}=2257.1717$; found $\mathrm{m} / \mathrm{z}=2257.1708[(\mathrm{M}$ $\left.+\mathrm{Na})^{+}, 100 \%\right]$.

General Procedure for the [G0]-[G3] Dendritic Diols 8a-d. A mixture of the $[\mathrm{G} n]$-dendritic diesters $7 \mathbf{a}-\mathbf{d}$ (1.0 equiv) and $\mathrm{NaBH}_{4}$ (4.0 equiv) in $\mathrm{MeOH} / \mathrm{THF}(1: 2 \mathrm{v} / \mathrm{v})(2 \mathrm{~mL} / \mathrm{mM})$ was stirred for $12 \mathrm{~h}$ at $0{ }^{\circ} \mathrm{C}$. The reaction mixture was then quenched with $\mathrm{H}_{2} \mathrm{O}$ at $0{ }^{\circ} \mathrm{C}$ and extracted twice with EtOAc. The organic phase extracts were combined and washed with brine, dried $\left(\mathrm{MgSO}_{4}\right)$, and filtered. The filtrate was evaporated under reduced pressure, and the residue was purified by column chromatography on silica gel with EtOAc as the eluent to afford the $[\mathrm{G} n]$-dendritic diols $\mathbf{8 a}-$ d.

[G0]-Dendritic Diol 8a. Starting from compound 7a (6.0 g, 17 $\mathrm{mmol})$ and $\mathrm{NaBH}_{4}(2.6 \mathrm{~g}, 67 \mathrm{mmol})$ in $\mathrm{MeOH} / \mathrm{THF}(150 \mathrm{~mL})$, the diol $8 \mathbf{a}(4.9 \mathrm{~g}, 97 \%$ yield) was obtained as a white solid. Mp: 89.2$91.4{ }^{\circ} \mathrm{C} .{ }^{1} \mathrm{H}$ NMR: $\delta=1.33(\mathrm{~s}, 9 \mathrm{H}), 2.60-3.10(\mathrm{bs}, 2 \mathrm{H}), 4.70$ (s, $4 \mathrm{H}), 5.08(\mathrm{~s}, 2 \mathrm{H}), 6.79(\mathrm{~s}, 2 \mathrm{H}), 7.34(\mathrm{~d}, J=8.3 \mathrm{~Hz}, 2 \mathrm{H})$, $7.43(\mathrm{~d}, J=8.3 \mathrm{~Hz}, 2 \mathrm{H}) .{ }^{13} \mathrm{C}$ NMR: $\delta=31.2,34.5,64.3,69.8$, $105.9,125.6,127.4,132.3,151.5,160.7,166.3$. MS (HRMALDI): calcd for $\mathrm{C}_{18} \mathrm{H}_{23} \mathrm{NO}_{3} \mathrm{Na} \mathrm{m} / \mathrm{z}=324.1576$; found $\mathrm{m} / \mathrm{z}=$ $324.1565\left[(\mathrm{M}+\mathrm{Na})^{+}, 100 \%\right]$.

[G1]-Dendritic Diol 8b. Starting from compound 7b (1.8 g, 2.9 $\mathrm{mmol}$ ) and $\mathrm{NaBH}_{4}(0.44 \mathrm{~g}, 12 \mathrm{mmol})$ in $\mathrm{MeOH} / \mathrm{THF}(30 \mathrm{~mL})$, the diol $\mathbf{8 b}$ (1.6 g, 98\% yield) was obtained as a white solid. Mp: 123.6-126.2 ${ }^{\circ} \mathrm{C} .{ }^{1} \mathrm{H}$ NMR: $\delta=1.33$ (s, $18 \mathrm{H}$ ), 3.20-3.60 (bs, 2 H), $4.69(\mathrm{~s}, 4 \mathrm{H}), 4.99(\mathrm{~s}, 4 \mathrm{H}), 5.05(\mathrm{~s}, 2 \mathrm{H}), 6.61(\mathrm{t}, J=2.8 \mathrm{~Hz}$, $1 \mathrm{H}), 6.64(\mathrm{~d}, J=2.8 \mathrm{~Hz}, 2 \mathrm{H}), 6.78(\mathrm{~s}, 2 \mathrm{H}), 7.36(\mathrm{~d}, J=8.3 \mathrm{~Hz}$, $4 \mathrm{H}), 7.41(\mathrm{~d}, J=8.3 \mathrm{~Hz}, 4 \mathrm{H}) .{ }^{13} \mathrm{C}$ NMR: $\delta=31.2,34.5,64.3$, $69.8,69.9,101.5,105.8,106.1,125.5,127.5,133.4,137.7,151.1$, 160.3, 166.1. MS (HR-MALDI): calcd for $\mathrm{C}_{36} \mathrm{H}_{43} \mathrm{NO}_{5} \mathrm{Na} \mathrm{m} / \mathrm{z}=$ 592.3039; found $\mathrm{m} / \mathrm{z}=592.3014\left[(\mathrm{M}+\mathrm{Na})^{+}, 100 \%\right]$.

[G2]-Dendritic Diol 8c. Starting from compound 7c (0.6 g, 0.52 mmol) and $\mathrm{NaBH}_{4}(79 \mathrm{mg}, 2.1 \mathrm{mmol})$ in $\mathrm{MeOH} / \mathrm{THF}(15 \mathrm{~mL})$, the diol $8 \mathbf{c}(0.51 \mathrm{~g}, 88 \%$ yield $)$ was obtained as a colorless glassy solid. ${ }^{1} \mathrm{H}$ NMR $(\mathrm{OH}$ signal not observed): $\delta=1.33(\mathrm{~s}, 36 \mathrm{H})$, $4.69(\mathrm{~s}, 4 \mathrm{H}), 4.99(\mathrm{~s}, 12 \mathrm{H}), 5.06(\mathrm{~s}, 2 \mathrm{H}), 6.50-6.60(\mathrm{~m}, 3 \mathrm{H})$, $6.62(\mathrm{~d}, J=2.8 \mathrm{~Hz}, 2 \mathrm{H}), 6.68(\mathrm{~d}, J=2.8 \mathrm{~Hz}, 4 \mathrm{H}), 6.77(\mathrm{~s}, 2 \mathrm{H})$, $7.35(\mathrm{~d}, J=8.3 \mathrm{~Hz}, 8 \mathrm{H}), 7.41(\mathrm{~d}, J=8.3 \mathrm{~Hz}, 8 \mathrm{H}) .{ }^{13} \mathrm{C}$ NMR: $\delta=31.2,34.5,64.1,69.9,70.0,101.3,101.7,105.8,106.2,125.5$, $127.5,133.5,138.9,151.0,160.1,160.2,166.3$. MS (HRMALDI): calcd for $\mathrm{C}_{72} \mathrm{H}_{83} \mathrm{NO}_{9} \mathrm{Na} \mathrm{m} / \mathrm{z}=1128.5966$; found $\mathrm{m} / \mathrm{z}=$ $1128.5980\left[(\mathrm{M}+\mathrm{Na})^{+}, 100 \%\right]$.

[G3]-Dendritic Diol 8d. Starting from compound 7d (1.1 g, 0.49 $\mathrm{mmol})$ and $\mathrm{NaBH}_{4}(74 \mathrm{mg}, 2.0 \mathrm{mmol})$ in $\mathrm{MeOH} / \mathrm{THF}(10 \mathrm{~mL})$, the diol 8d (0.8 g, 75\% yield) was obtained as a colorless glassy solid. ${ }^{1} \mathrm{H}$ NMR $(\mathrm{OH}$ signal not observed): $\delta=1.32(\mathrm{~s}, 72 \mathrm{H})$, 4.66 (s, $4 \mathrm{H}), 4.97(\mathrm{~s}, 28 \mathrm{H}), 5.01(\mathrm{~s}, 2 \mathrm{H}), 6.53-6.75(\mathrm{~m}, 23 \mathrm{H})$, $7.34(\mathrm{~d}, J=8.3 \mathrm{~Hz}, 16 \mathrm{H}), 7.39(\mathrm{~d}, J=8.3 \mathrm{~Hz}, 16 \mathrm{H}) .{ }^{13} \mathrm{C} \mathrm{NMR}$ : $\delta=31.2,34.5,64.2,69.7,69.9,70.0,101.3,101.7,105.8,106.2$, $125.4,125.5,127.5,133.5,138.9,151.0,160.0,160.1,160.2,166.3$. MS (HR-ESI): calcd for $\mathrm{C}_{144} \mathrm{H}_{164} \mathrm{NO}_{17} \mathrm{~m} / \mathrm{z}=2179.1994$; found $m / z=2179.1931\left[(\mathrm{M}+\mathrm{H})^{+}, 100 \%\right]$.

General Procedure for [G0]-[G3] Dendritic Dialdehydes $\mathbf{1 a}-\mathbf{d}$. A mixture of the $[\mathrm{G} n]$-dendritic diols $\mathbf{8 a}-\mathbf{d}$ (1.0 equiv) and $\mathrm{SeO}_{2}$ (6.0 equiv) in 1,4-dioxane $(2 \mathrm{~mL} / \mathrm{mM})$ was stirred for $12 \mathrm{~h}$ at $100{ }^{\circ} \mathrm{C}$. The reaction mixture was cooled to $25^{\circ} \mathrm{C}$ and then quenched with $\mathrm{H}_{2} \mathrm{O}$, followed by the extraction with EtOAc twice. The organic phase extracts were combined and washed with brine, dried $\left(\mathrm{MgSO}_{4}\right)$, and filtered. The filtrate was evaporated under reduced pressure, and the residue was purified by column chromatography on silica gel with hexane/EtOAc $(4: 1)$ as the eluent to afford the $[\mathrm{G} n]$-dendritic dialdehydes $\mathbf{1 a}-\mathbf{d}$.

[G0]-Dendritic Dialdehyde 1a. Starting from compound 8a $(0.15 \mathrm{~g}, 0.50 \mathrm{mmol})$ and $\mathrm{SeO}_{2}(0.33 \mathrm{~g}, 3.0 \mathrm{mmol})$ in 1,4-dioxane (3 mL), the dialdehyde 1a (61 mg, 41\% yield) was obtained as a white solid. Mp: $73.3-75.2^{\circ} \mathrm{C} ;{ }^{1} \mathrm{H}$ NMR $\left(\mathrm{CD}_{3} \mathrm{CN}\right): \delta=1.35$ (s, $9 \mathrm{H}), 5.28(\mathrm{~s}, 2 \mathrm{H}), 7.42(\mathrm{~d}, J=8.3 \mathrm{~Hz}, 2 \mathrm{H}), 7.50(\mathrm{~d}, J=8.3 \mathrm{~Hz}$, $2 \mathrm{H}), 7.72(\mathrm{~s}, 2 \mathrm{H}), 10.06(\mathrm{~s}, 2 \mathrm{H}) .{ }^{13} \mathrm{C}$ NMR $\left(\mathrm{CD}_{3} \mathrm{CN}\right): \delta=30.4$, 34.1, 70.6, 111.5, 125.5, 127.8, 132.3, 151.6, 154.8, 166.9, 192.3. MS (HR-ESI): calcd for $\mathrm{C}_{18} \mathrm{H}_{19} \mathrm{NO}_{3} \mathrm{~m} / \mathrm{z}=297.1365$; found $\mathrm{m} / \mathrm{z}$ $=297.1365\left[\mathrm{M}^{+}, 100 \%\right]$.

[G1]-Dendritic Dialdehyde 1b. Starting from compound $\mathbf{8 b}$ $(0.50 \mathrm{~g}, 0.88 \mathrm{mmol})$ and $\mathrm{SeO}_{2}(0.59 \mathrm{~g}, 5.3 \mathrm{mmol})$ in 1,4-dioxane $(20 \mathrm{~mL})$, the dialdehyde $\mathbf{1 b}(0.20 \mathrm{~g}, 40 \%$ yield $)$ was obtained as a white solid. Mp: $139.4-141.2{ }^{\circ} \mathrm{C} .{ }^{1} \mathrm{H}$ NMR $\left(\mathrm{CD}_{3} \mathrm{CN}\right): \delta=1.34$ $(\mathrm{s}, 18 \mathrm{H}), 5.07(\mathrm{~s}, 4 \mathrm{H}), 5.27(\mathrm{~s}, 2 \mathrm{H}), 6.61(\mathrm{t}, J=2.8 \mathrm{~Hz}, 1 \mathrm{H})$, $6.67(\mathrm{~d}, J=2.8 \mathrm{~Hz}, 2 \mathrm{H}), 7.38(\mathrm{~d}, J=8.3 \mathrm{~Hz}, 4 \mathrm{H}), 7.46(\mathrm{~d}, J=$ $8.3 \mathrm{~Hz}, 4 \mathrm{H}), 7.73(\mathrm{~s}, 2 \mathrm{H}), 10.08(\mathrm{~s}, 2 \mathrm{H}) .{ }^{13} \mathrm{C} \mathrm{NMR}\left(\mathrm{CDCl}_{3}\right): \delta$ $=31.2,34.5,70.0,70.7,101.9,106.2,111.7,125.5,127.4,133.3$, 136.6, 151.1, 154.7, 160.4, 166.5, 192.1. MS (HR-MALDI): calcd for $\mathrm{C}_{36} \mathrm{H}_{39} \mathrm{NO}_{5} \mathrm{Na} \mathrm{m} / \mathrm{z}=588.2726$; found $\mathrm{m} / \mathrm{z}=588.2730[(\mathrm{M}+$ $\left.\mathrm{Na})^{+}, 100 \%\right]$.

[G2]-Dendritic Dialdehyde 1c. Starting from compound 8c $(0.35$ $\mathrm{g}, 0.32 \mathrm{mmol})$ and $\mathrm{SeO}_{2}(0.21 \mathrm{~g}, 1.9 \mathrm{mmol})$ in 1,4-dioxane $(15$ $\mathrm{mL})$, the dialdehyde $1 \mathrm{c}(0.15 \mathrm{~g}, 43 \%$ yield $)$ was obtained as a colorless glassy solid. ${ }^{1} \mathrm{H}$ NMR $\left(\mathrm{CD}_{3} \mathrm{CN}\right): \delta=1.28(\mathrm{~s}, 36 \mathrm{H}), 4.96$ $(\mathrm{s}, 12 \mathrm{H}), 5.18(\mathrm{~s}, 2 \mathrm{H}), 6.48(\mathrm{t}, J=2.8 \mathrm{~Hz}, 2 \mathrm{H}), 6.54(\mathrm{t}, J=2.8$ $\mathrm{Hz}, 1 \mathrm{H}), 6.61(\mathrm{~d}, J=2.8 \mathrm{~Hz}, 2 \mathrm{H}), 6.65(\mathrm{~d}, J=2.8 \mathrm{~Hz}, 4 \mathrm{H})$, $7.30(\mathrm{~d}, J=8.3 \mathrm{~Hz}, 8 \mathrm{H}), 7.39(\mathrm{~d}, J=8.3 \mathrm{~Hz}, 8 \mathrm{H}), 7.63(\mathrm{~s}, 2 \mathrm{H})$, $9.98(\mathrm{~s}, 2 \mathrm{H}) .{ }^{13} \mathrm{C} \mathrm{NMR}\left(\mathrm{CD}_{3} \mathrm{CN}\right): \delta=31.2,34.5,69.9,70.0$, 70.6, 101.4, 102.0, 106.1, 106.3, 111.7, 125.4, 127.5, 133.5, 136.7, 138.8, 151.0, 154.7, 160.2, 166.5, 192.1. MS (HR-MALDI): calcd for $\mathrm{C}_{72} \mathrm{H}_{79} \mathrm{NO}_{9} \mathrm{Na} \mathrm{m} / \mathrm{z}=1124.5653$; found $\mathrm{m} / z=1124.5551[(\mathrm{M}$ $\left.+\mathrm{Na})^{+}, 100 \%\right]$.

[G3]-Dendritic Dialdehyde 1d. Starting from compound 8d $(0.80 \mathrm{~g}, 0.37 \mathrm{mmol})$ and $\mathrm{SeO}_{2}(0.25 \mathrm{~g}, 2.2 \mathrm{mmol})$ in 1,4-dioxane $(10 \mathrm{~mL})$, the dialdehyde $1 \mathrm{~d}(0.40 \mathrm{~g}, 50 \%$ yield $)$ was obtained as a colorless glassy solid. ${ }^{1} \mathrm{H}$ NMR: $\delta=1.31(\mathrm{~s}, 72 \mathrm{H}), 4.97(\mathrm{~s}, 28$ $\mathrm{H}), 5.11(\mathrm{~s}, 2 \mathrm{H}), 6.54-6.70(\mathrm{~m}, 21 \mathrm{H}), 7.34(\mathrm{~d}, J=8.3 \mathrm{~Hz}, 16$ $\mathrm{H}), 7.39(\mathrm{~d}, J=8.3 \mathrm{~Hz}, 16 \mathrm{H}), 7.65(\mathrm{~s}, 2 \mathrm{H}), 10.01(\mathrm{~s}, 2 \mathrm{H}) .{ }^{13} \mathrm{C}$ NMR: $\delta=31.2,34.5,69.7,69.9,70.0,101.3,101.7,105.8,106.2$, $125.4,125.5,127.5,133.5,138.9,151.0,160.0,160.1,160.2,166.3$, 191.9. MS (HR-MALDI): calcd for $\mathrm{C}_{144} \mathrm{H}_{159} \mathrm{NO}_{17} \mathrm{Na} \mathrm{m} / \mathrm{z}=$ 2197.1500; found $\mathrm{m} / z=2197.1449\left[(\mathrm{M}+\mathrm{Na})^{+}, 100 \%\right]$.

General Procedure for the Dynamic [G0]-[G3] Dendrimers $\mathbf{4 a}-\mathbf{d}-\mathbf{H}_{3} \cdot \mathbf{3 P F}_{\mathbf{6}}$. The $[\mathrm{G} n]$-dendritic dialdehydes $\mathbf{1 a}-\mathbf{d}$ (3.0 equiv), the diamine 2 (3.0 equiv) and the trisammonium salt $3-\mathrm{H}_{3} \cdot 3 \mathrm{PF}_{6}$ (1.0 equiv) were mixed together in either $\mathrm{CD}_{3} \mathrm{NO}_{2}$ (total concentration $=35 \mathrm{mM}$ ) or $\mathrm{CD}_{3} \mathrm{CN}$ (total concentration $=35 \mathrm{mM}$ ) at $25^{\circ} \mathrm{C}$ for $20 \mathrm{~min}$. Subsequently, the excess solvent was removed under reduced pressure to give the $[\mathrm{G} n]$-dendrimers $\mathbf{4 a}-\mathbf{d}-\mathrm{H}_{3} \cdot 3 \mathrm{PF}_{6}$.

Dynamic [G0] Dendrimer $\mathbf{4 a}-\mathbf{H}_{\mathbf{3}} \cdot \mathbf{3 P F}_{\mathbf{6}}$. Starting from the [G0]dendritic dialdehyde $\mathbf{1 a}(10 \mathrm{mg}, 0.035 \mathrm{mmol})$, the diamine 2 (13 $\mathrm{mg}, 0.035 \mathrm{mmol})$, and the trisammonium salt $3-\mathrm{H}_{3} \cdot 3 \mathrm{PF}_{6}(15 \mathrm{mg}$, $0.012 \mathrm{mmol})$ in $\mathrm{MeNO}_{2}(1.0 \mathrm{~mL})$, the dendrimer $\mathbf{4 a}-\mathrm{H}_{3} \cdot 3 \mathrm{PF}_{6}(39$ $\mathrm{mg}$, quant.) was obtained as a yellowish glassy solid. ${ }^{1} \mathrm{H}$ NMR $\left(\mathrm{CD}_{3} \mathrm{NO}_{2}\right): \delta=1.23(\mathrm{~s}, 27 \mathrm{H}), 3.38(\mathrm{~s}, 18 \mathrm{H}), 3.61(\mathrm{bs}, 12 \mathrm{H})$, 3.71 (bs, $12 \mathrm{H}), 4.00-4.15$ (m, $18 \mathrm{H}), 4.60$ (bs, $6 \mathrm{H}), 4.63$ (bs, 6 $\mathrm{H}), 4.81(\mathrm{bs}, 6 \mathrm{H}), 4.87(\mathrm{~s}, 6 \mathrm{H}), 6.11(\mathrm{t}, J=2.2 \mathrm{~Hz}, 3 \mathrm{H}), 6.48(\mathrm{~d}$, $J=2.2 \mathrm{~Hz}, 6 \mathrm{H}), 6.91(\mathrm{~d}, J=7.7 \mathrm{~Hz}, 6 \mathrm{H}), 6.98-7.08(\mathrm{~m}, 6 \mathrm{H})$, $7.18-7.20(\mathrm{~m}, 6 \mathrm{H}), 7.22-7.30(\mathrm{~m}, 24 \mathrm{H}), 7.35-7.40(\mathrm{~m}, 6 \mathrm{H})$, $7.47(\mathrm{~d}, J=8.1 \mathrm{~Hz}, 6 \mathrm{H}), 7.52(\mathrm{~s}, 3 \mathrm{H}), 8.34(\mathrm{~s}, 6 \mathrm{H}), 10.07$ (bs, $6 \mathrm{H})$. MS (HR-ESI): calcd for $\mathrm{C}_{168} \mathrm{H}_{189} \mathrm{~N}_{12} \mathrm{O}_{24}{ }^{3+} \mathrm{m} / \mathrm{z}=919.4646$; found $m / z=919.4633\left[\left(\mathrm{M}-3 \mathrm{PF}_{6}\right)^{3+}, 100 \%\right]$.

Dynamic [G1] Dendrimer $\mathbf{4 b}-\mathbf{H}_{3} \cdot \mathbf{3 P F}_{\mathbf{6}}$. Starting from the [G1] dendritic dialdehyde $\mathbf{1 b}(20 \mathrm{mg}, 0.035 \mathrm{mmol})$, the diamine $\mathbf{2}$ (13 
$\mathrm{mg}, 0.035 \mathrm{mmol})$, and the trisammonium salt $3-\mathrm{H}_{3} \cdot 3 \mathrm{PF}_{6}(15 \mathrm{mg}$, $0.012 \mathrm{mmol})$ in $\mathrm{MeNO}_{2}(1.0 \mathrm{~mL})$, the dendrimer $\mathbf{4} \mathbf{b}-\mathrm{H}_{3} \cdot 3 \mathrm{PF}_{6}(48$ $\mathrm{mg}$, quant.) was obtained as a yellowish glassy solid. ${ }^{1} \mathrm{H} \mathrm{NMR}\left(\mathrm{CD}_{3^{-}}\right.$ $\left.\mathrm{NO}_{2}\right): \delta=1.25(\mathrm{~s}, 54 \mathrm{H}), 3.36(\mathrm{~s}, 18 \mathrm{H}), 3.57(\mathrm{bs}, 12 \mathrm{H}), 3.65$ (bs, $12 \mathrm{H}), 3.93-4.10(\mathrm{~m}, 24 \mathrm{H}), 4.55$ (bs, $6 \mathrm{H}), 4.74$ (bs, $6 \mathrm{H})$, $4.83(\mathrm{~s}, 6 \mathrm{H}), 4.87(\mathrm{~s}, 12 \mathrm{H}), 6.10(\mathrm{bs}, 3 \mathrm{H}), 6.45(\mathrm{~d}, J=2.3 \mathrm{~Hz}$, $6 \mathrm{H}), 6.53(\mathrm{~s}, 3 \mathrm{H}), 6.82(\mathrm{~d}, J=7.8 \mathrm{~Hz}, 6 \mathrm{H}), 6.99(\mathrm{t}, J=7.8 \mathrm{~Hz}$, $6 \mathrm{H}), 7.12(\mathrm{~s}, 6 \mathrm{H}), 7.15-7.50(\mathrm{~m}, 54 \mathrm{H}), 7.56(\mathrm{~s}, 3 \mathrm{H}), 8.23(\mathrm{~s}, 6$ $\mathrm{H}), 10.02$ (bs, $6 \mathrm{H})$. MS (HR-ESI): calcd for $\mathrm{C}_{222} \mathrm{H}_{249} \mathrm{~N}_{12} \mathrm{O}_{30}{ }^{3+}$ $\mathrm{m} / \mathrm{z}=1187.6109$; found $\mathrm{m} / \mathrm{z}=1187.6109\left[\left(\mathrm{M}-3 \mathrm{PF}_{6}\right)^{3+}, 100 \%\right]$.

Dynamic [G2] Dendrimer $\mathbf{4} \mathbf{c}-\mathbf{H}_{\mathbf{3}} \cdot \mathbf{3 P F}_{\mathbf{6}}$. Starting from the [G2]dendritic dialdehyde $\mathbf{1 c}(39 \mathrm{mg}, 0.035 \mathrm{mmol})$, the diamine 2 (13 $\mathrm{mg}, 0.035 \mathrm{mmol})$, and the trisammonium salt $3-\mathrm{H}_{3} \cdot 3 \mathrm{PF}_{6}(15 \mathrm{mg}$, $0.012 \mathrm{mmol})$ in $\mathrm{MeNO}_{2}(1.0 \mathrm{~mL})$, the dendrimer $\mathbf{4} \mathbf{c}-\mathrm{H}_{3} \cdot 3 \mathrm{PF}_{6}(67$ $\mathrm{mg}$, quant.) was obtained as a yellowish glassy solid. ${ }^{1} \mathrm{H} \mathrm{NMR}\left(\mathrm{CD}_{3^{-}}\right.$ $\left.\mathrm{NO}_{2}\right): \delta=1.25(\mathrm{~s}, 108 \mathrm{H}), 3.30-3.35(\mathrm{~m}, 18 \mathrm{H}), 3.51(\mathrm{~d}, J=3.2$ $\mathrm{Hz}, 12 \mathrm{H}), 3.64$ (d, $J=3.2 \mathrm{~Hz}, 12 \mathrm{H}), 3.86-3.97$ (m, $24 \mathrm{H}), 4.46$ (bs, $6 \mathrm{H}), 4.69$ (bs, $6 \mathrm{H}), 4.76(\mathrm{~s}, 6 \mathrm{H}), 4.80$ (s, $12 \mathrm{H}), 4.91$ (s, 24 H), 6.08 (bs, $3 \mathrm{H}), 6.38$ (d, $J=2.1 \mathrm{~Hz}, 6 \mathrm{H}), 6.45$ (bs, $6 \mathrm{H}), 6.50$ (bs, $3 \mathrm{H}), 6.53$ (bs, $6 \mathrm{H}), 6.60(\mathrm{~d}, J=2.1 \mathrm{~Hz}, 12 \mathrm{H}), 6.70$ (d, $J=$ $7.5 \mathrm{~Hz}, 6 \mathrm{H}), 6.93(\mathrm{t}, J=7.5 \mathrm{~Hz}, 6 \mathrm{H}), 7.00(\mathrm{~s}, 6 \mathrm{H}), 7.14(\mathrm{~d}, J=$ $8.4 \mathrm{~Hz}, 6 \mathrm{H}), 7.20-7.45(\mathrm{~m}, 66 \mathrm{H}), 7.59$ (s, $3 \mathrm{H}), 8.09$ (s, $6 \mathrm{H})$, 9.98 (bs, $6 \mathrm{H})$. MS (HR-ESI): calcd for $\mathrm{C}_{330} \mathrm{H}_{369} \mathrm{~N}_{12} \mathrm{O}_{42}{ }^{3+} \mathrm{m} / \mathrm{z}=$

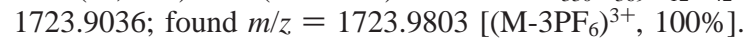

Dynamic [G3] Dendrimer $\mathbf{4} \mathbf{d}-\mathbf{H}_{3} \cdot \mathbf{3 P F}_{\mathbf{6}}$. Starting from the [G3]dendritic dialdehyde $\mathbf{1 d}(76 \mathrm{mg}, 0.035 \mathrm{mmol})$, the diamine 2 (13 $\mathrm{mg}, 0.035 \mathrm{mmol})$, and the trisammonium salt $3-\mathrm{H}_{3} \cdot 3 \mathrm{PF}_{6}(15 \mathrm{mg}$, $0.012 \mathrm{mmol})$ in $\mathrm{MeNO}_{2} / \mathrm{CH}_{2} \mathrm{Cl}_{2}(2: 1,1.0 \mathrm{~mL})$, the dendrimer $4 \mathbf{d}$ $\mathrm{H}_{3} \cdot 3 \mathrm{PF}_{6}(0.10 \mathrm{~g}$, quant.) was obtained as a yellowish glassy solid. ${ }^{1} \mathrm{H}$ NMR $\left(\mathrm{CD}_{3} \mathrm{NO}_{2} / \mathrm{CD}_{2} \mathrm{Cl}_{2} 3: 1\right): \delta=1.32(\mathrm{~s}, 216 \mathrm{H}), 3.35(\mathrm{~s}, 18$ $\mathrm{H}), 3.70-3.73(\mathrm{~m}, 24 \mathrm{H}), 3.90(\mathrm{t}, J=4.6 \mathrm{~Hz}, 12 \mathrm{H}), 4.20(\mathrm{t}, J=$ $4.6 \mathrm{~Hz}, 12 \mathrm{H}), 4.65$ (bs, $6 \mathrm{H}), 4.80-5.10$ (m, $96 \mathrm{H}), 6.10$ (bs, 3 $\mathrm{H}), 6.40$ (bs, $6 \mathrm{H}), 6.50-6.70(\mathrm{~m}, 63 \mathrm{H}), 6.70-6.78(\mathrm{~m}, 12 \mathrm{H})$, $6.82(\mathrm{~d}, J=7.9 \mathrm{~Hz}, 6 \mathrm{H}), 6.88(\mathrm{~d}, J=7.9 \mathrm{~Hz}, 6 \mathrm{H}), 7.08(\mathrm{~s}, 6 \mathrm{H})$, 7.35-7.50 (m, $108 \mathrm{H}), 7.54$ (s, $3 \mathrm{H}), 8.05$ (s, $6 \mathrm{H}), 9.90-10.12$ (b, $6 \mathrm{H})$. MS (HR-ESI): calcd for $\mathrm{C}_{546} \mathrm{H}_{609} \mathrm{~N}_{12} \mathrm{O}_{66}{ }^{3+} \mathrm{m} / \mathrm{z}=2796.4883$; found $m / z=2796.5769\left[\left(\mathrm{M}-3 \mathrm{PF}_{6}\right)^{3+}, 100 \%\right]$.

General Procedure for Neutral [G0]-[G2] Dendrimers 9a-c. A solution of $\mathrm{BH}_{3} \cdot$ THF complex (1.8 M in THF) (12 equiv) was added to a $\mathrm{CD}_{3} \mathrm{NO}_{2}$ or $\mathrm{CD}_{3} \mathrm{CN}$ solution of the $[\mathrm{G} n]$-dendrimers $4 \mathbf{a}-\mathbf{c}-\mathrm{H}_{3} \cdot 3 \mathrm{PF}_{6}$ at $25^{\circ} \mathrm{C}$. After standing for $6 \mathrm{~h}$, the reaction mixture was quenched with $\mathrm{NaOH}$ solution $(2 \mathrm{M})$ to a $\mathrm{pH} \sim 8$ and extracted twice with $\mathrm{CHCl}_{3}$. The organic phase extracts were combined and washed with brine, dried $\left(\mathrm{MgSO}_{4}\right)$ and filtered. The filtrate was evaporated under reduced pressure to give the neutral $[\mathrm{G} n]$ dendrimers $\mathbf{9 a}-\mathbf{c}$

Neutral [G0]-Dendrimer 9a. Starting from the dynamic [G0]dendrimer $\mathbf{4 a}-\mathrm{H}_{3} \cdot 3 \mathrm{PF}_{6}(37 \mathrm{mg}, 0.012 \mathrm{mmol}$ ), the dendrimer $\mathbf{9 a}(29$ $\mathrm{mg}, 90 \%$ yield) was obtained as a colorless glassy solid. ${ }^{1} \mathrm{H}$ NMR: $\delta=1.32(\mathrm{~s}, 27 \mathrm{H}), 1.70-1.85(\mathrm{~b}, 3 \mathrm{H}), 3.35(\mathrm{~s}, 18 \mathrm{H}), 3.52-3.90$ (m, $42 \mathrm{H}), 3.96-4.28(\mathrm{~m}, 18 \mathrm{H}), 4.49$ (bs, $6 \mathrm{H}), 4.60$ (bs, $6 \mathrm{H})$, $4.97(\mathrm{~s}, 12 \mathrm{H}), 6.09(\mathrm{t}, J=7.2 \mathrm{~Hz}, 3 \mathrm{H}), 6.38(\mathrm{~d}, J=7.2 \mathrm{~Hz}, 6 \mathrm{H})$, 6.59-6.72 (m, $24 \mathrm{H}), 6.80-7.04(\mathrm{~m}, 12 \mathrm{H}), 7.35-7.44(\mathrm{~m}, 21 \mathrm{H})$. ${ }^{13} \mathrm{C}$ NMR: $\delta=31.2,34.5,55.2,62.7,67.9,69.8,69.9,70.6,72.7$, $106.3,106.5,110.0,111.7,112.3,119.4,121.1,122.9,125.4,127.5$, 127.6, 129.1, 133.6, 146.0, 151.0, 160.0, 160.1, 160.2, 161.0. MS (HR-MALDI): calcd for $\mathrm{C}_{168} \mathrm{H}_{198} \mathrm{~N}_{12} \mathrm{O}_{24} \mathrm{~m} / \mathrm{z}=2767.4637$; found $m / z=2767.4680\left[\mathrm{M}^{+}, 100 \%\right]$.

Neutral [G1]-Dendrimer 9b. Starting from the dynamic [G1]dendrimer $\mathbf{4 b}-\mathrm{H}_{3} \cdot 3 \mathrm{PF}_{6}(46 \mathrm{mg}, 0.012 \mathrm{mmol}$ ), the dendrimer $\mathbf{9 b}$ (37 mg, $91 \%$ yield) was obtained as a colorless glassy solid. ${ }^{1} \mathrm{H}$ NMR: $\delta=1.31(\mathrm{~s}, 54 \mathrm{H}), 1.65-1.72(\mathrm{~b}, 3 \mathrm{H}), 3.35-3.50(\mathrm{~m}, 24 \mathrm{H})$, $3.54(\mathrm{t}, J=5.2 \mathrm{~Hz}, 12 \mathrm{H}), 3.65(\mathrm{t}, J=5.2 \mathrm{~Hz}, 12 \mathrm{H}), 3.68-3.75$ (m, $12 \mathrm{H}), 3.79-3.85(\mathrm{~m}, 18 \mathrm{H}), 4.09(\mathrm{bs}, 12 \mathrm{H}), 4.14(\mathrm{bs}, 6 \mathrm{H})$, 4.95 (bs, $6 \mathrm{H}), 4.96$ (s, $12 \mathrm{H}), 6.20$ (bs, $3 \mathrm{H}), 6.52-6.65$ (m, 15 $\mathrm{H}), 6.84-6.90(\mathrm{~m}, 6 \mathrm{H}), 7.30-7.45(\mathrm{~m}, 63 \mathrm{H}) .{ }^{13} \mathrm{C} \mathrm{NMR}: \delta=$ 31.2, 34.5, 55.3, 62.8, 67.9, 69.9, 70.0, 70.6, 72.7, 101.6, 106.2, 106.3, 106.5, 110.0, 111.7, 112.3, 119.4, 121.1, 122.9, 125.4, 127.5, 129.1, 133.6, 138.9, 146.1, 151.1, 160.1, 160.2, 161.0, 161.1. MS (HR-MALDI): calcd for $\mathrm{C}_{222} \mathrm{H}_{258} \mathrm{~N}_{12} \mathrm{O}_{30} \mathrm{~m} / z=3571.9031$; found $m / z=3572.0780\left[\mathrm{M}^{+}, 100 \%\right]$.
Neutral [G2]-Dendrimer 9c. Starting from the dynamic [G2]dendrimer $\mathbf{4} \mathbf{c}-\mathrm{H}_{3} \cdot 3 \mathrm{PF}_{6}(65 \mathrm{mg}, 0.012 \mathrm{mmol})$, the dendrimer $\mathbf{9 c}(55$ $\mathrm{mg}, 91 \%$ yield) was obtained as a colorless glassy solid. ${ }^{1} \mathrm{H}$ NMR: $\delta=1.31(\mathrm{~s}, 108 \mathrm{H}), 1.64-1.71(\mathrm{~b}, 3 \mathrm{H}), 3.40-3.60(\mathrm{~m}, 24 \mathrm{H})$, $3.64-3.75(\mathrm{~m}, 24 \mathrm{H}), 3.79-3.90(\mathrm{~m}, 24 \mathrm{H}), 3.99-4.10(\mathrm{bs}, 30$ H), 4.15 (bs, $18 \mathrm{H}), 4.42$ (bs, $6 \mathrm{H}), 4.95$ (s, $12 \mathrm{H}), 6.15$ (bs, $3 \mathrm{H})$, 6.50-6.65 (m, $33 \mathrm{H}), 6.65-6.70(\mathrm{~m}, 12 \mathrm{H}), 6.74-6.88(\mathrm{~m}, 6 \mathrm{H})$, 7.30-7.45 (m, $75 \mathrm{H}) .{ }^{13} \mathrm{C}$ NMR: $\delta=31.2,34.5,55.2,62.7,67.9$, $69.8,69.9,70.0,70.6,72.7,101.5,106.2,106.3,106.5,110.0,111.7$, $112.3,119.4,121.1,122.9,125.4,127.5,127.6,129.1,133.6,138.9$, $146.0,151.0,160.0,160.1,160.2,160.9,161.0$. MS (HRMALDI): calcd for $\mathrm{C}_{330} \mathrm{H}_{378} \mathrm{~N}_{12} \mathrm{O}_{42} \mathrm{~m} / \mathrm{z}=5180.7812$; found $\mathrm{m} / \mathrm{z}$ $=5181.0500\left[\mathrm{M}^{+}, 100 \%\right]$.

Acknowledgment. This research was conducted as part of an NSF-NIRT award (ECS-0404458). K.C-F.L. is supported by the Croucher Foundation in Hong Kong. We thank Professor Hak-Fun Chow (Chinese University of Hong Kong) for very helpful discussions.

Supporting Information Available: Mass spectra and gel permeation chromatogram. This material is available free of charge via the Internet at http://pubs.acs.org.

\section{References and Notes}

(1) (a) Brady, P. A.; Bonar-Law, R. P.; Rowan, S. J.; Suckling, C. J ; Sanders, J. K. M. Chem. Commun. 1996, 319-320. (b) Brady, P. A.; Sanders, J. K. M. Chem. Soc. Rev. 1997, 26, 327-336. (c) Mohr, B.; Weck, M.; Sauvage, J.-P.; Grubbs, R. H. Angew. Chem., Int. Ed. Engl. 1997, 36, 1308-1310. (d) Dietrich-Buchecker, C. O.; Rapenne, G. N.; Sauvage, J.-P. Chem. Commun. 1997, 2053-2054. (e) Hamilton, D. G.; Feeder, N.; Teat, S. J.; Sanders, J. K. M. New J. Chem. 1998 , 1019-1021. (f) Weck, M.; Mohr, B.; Sauvage, J.-P.; Grubbs, R. H. J. Org. Chem. 1999, 64, 5463-5471. (g) Lehn, J.-M. Chem.-Eur. J. 1999, 5, 2455-2463. (h) Cantrill, S. J.; Rowan, S. J.; Stoddart, J. F. Org. Lett. 1999, 1, 1363-1366. (i) Kidd, T. J.; Leigh, D. A.; Wilson, A. J. J. Am. Chem. Soc. 1999, 121, 1599-1600. (j) Belfrekh, N.; Dietrich-Buchecker, C. O.; Sauvage, J.-P. Inorg. Chem. 2000, 39, 5169-5172. (k) Rowan, S. J.; Cantrill, S. J.; Cousins, G. R. L.; Sanders, J. K. M.; Stoddart, J. F. Angew. Chem., Int. Ed. 2002, 41, 898-952. (1) Fuchs, B.; Nelson, A.; Star, A.; Stoddart, J. F. Angew. Chem., Int. Ed. 2003, 42, 4220-4224. (m) Aricó, F.; Mobian, P.; Kern, J.-M.; Sauvage, J.-P. Org. Lett. 2003, 11, 1887-1890. (n) Mobian, P.; Kern, J.-M.; Sauvage, J.-P. Angew. Chem., Int. Ed. 2004, 43, 23922395. (o) Guidry, E. N.; Cantrill, S. J.; Stoddart, J. F.; Grubbs, R. H. Org. Lett. 2005, 7, 2129-2132.

(2) Lam, R. T. S.; Belenguer, A.; Roberts, S. L.; Naumann, C.; Jarrosson, T.; Otto, S.; Sanders, J. K. M. Science 2005, 308, 667-669.

(3) (a) Glink, P. T.; Oliva, A. I.; Stoddart, J. F.; White, A. J. P.; Williams, D. J. Angew. Chem., Int. Ed. 2001, 40, 1870-1875. (b) Horn, M.; Ihringer, J.; Glink, P. T.; Stoddart, J. F. Chem.-Eur. J. 2003, 9, 40464054. (c) Kilbinger, A. F. M.; Cantrill, S. J.; Waltman, A. W.; Day, M. W.; Grubbs, R. H. Angew. Chem., Int. Ed. 2003, 42, 3281-3285. (d) Hannam, J. S.; Kidd, J. T.; Leigh, D. A.; Wilson, A. J. Org. Lett. 2003, 5, 1907-1910. (e) Fuller, A.-M.; Leigh, D. A.; Lusby, P. J.; Oswald, I. D. H.; Parsons, S.; Walker, D. B. Angew. Chem., Int. Ed. 2004, 43, 3914-3918. (f) Aricó, F.; Chang, T.; Cantrill, S. J.; Khan, S. I.; Stoddart, J. F. Chem.-Eur. J. 2005, 11, 4655-4666.

(4) Badjic, J. D.; Cantrill, S. J.; Grubbs, R. H.; Guidry, E. N.; Orenes, R.; Stoddart, J. F. Angew. Chem., Int. Ed. 2004, 43, 3273-3278.

(5) (a) Chichak, K. S.; Cantrill, S. J.; Pease, A. R.; Chiu, S.-H.; Cave, G. W. V.; Atwood, J. L.; Stoddart, J. F. Science 2004, 304, 1308-1312. (b) Cantrill, S. J.; Chichak, K. S.; Peters, A. J.; Stoddart, J. F. Acc Chem. Res. 2005, 1-9. (c) Chichak, K. S.; Cantrill, S. J.; Stoddart, J. F. Chem. Commun. 2005, 3391-3393. (d) Peters, A. J.; Chichak, K. S.; Cantrill, S. J.; Stoddart, J. F. Chem. Commun. 2005, 3394-3396. (e) Chichak, K. S.; Peters, A. J.; Cantrill, S. J.; Stoddart, J. F. J. Org. Chem. 2005, 70, 7956-7962. (f) Pentecost, C. D.; Peters, A. J.; Chichak, K. S.; Cave, G. W. V.; Cantrill, S. J.; Stoddart, J. F. Angew. Chem., Int. Ed. 2006, 45, 4099-4104.

(6) (a) Busch, D. H.; Stephenson, N. A. Coord. Chem. Rev. 1990, 100 119-154. (b) Philp, D.; Stoddart, J. F. Synlett 1991, 445-458. (c) Anderson, S.; Anderson, H. L.; Sanders, J. K. M. Acc. Chem. Res. 1993, 26, 469-475. (d) Sneider, J. P.; Kelly, J. W. Chem. Rev. 1995, 95, 2169-2187. (e) Raymo, F. M.; Stoddart, J. F. Pure Appl. Chem. 1996, 68, 313-322. (f) Stoddart, J. F.; Tseng, H.-R. Proc. Natl. Acad. Sci. U.S.A. 2002, 99, 4797-4800. 
(7) Diederich, F., Stang, P. J., Eds. Templated Organic Synthesis; WileyVCH: Weinheim, Germany, 1999.

(8) For reviews and selected publications in dendrimer chemistry: (a) Fréchet, J. M. J.; Tomalia, D. A. Dendrimers and Other Dendritic Polymers, Wiley: New York, 2002. (b) Newkome, G. R.; Vögtle, F.; Moorefield, C. N. Dendrimers and Dendrons: Concepts, Syntheses, Applications, VCH: New York, 2001. (c) Chow, H.-F.; Mong, T. K.K.; Nongrum, M. F.; Wan, C.-W. Tetrahedron 1998, 8543-8660. (d) Matthews, O. A.; Shipway, A. N.; Stoddart, J. F. Prog. Polym. Sci. 1998, 23, 1-56. (e) Bosman, A. W.; Janssen, H. M.; Meijer, E. W Chem. Rev. 1999, 99, 1665-1688. (f) Stoddart, F. J.; Welton, T. Polyhedron 1999, 18, 3575-3591. (g) Vögtle, F.; Gestermann, S.; Hesse, R.; Schwierz, H.; Windisch, B. Prog. Polym. Sci. 2000, 25 , 987-1041. (h) Tomalia, D. A. Prog. Polym. Sci. 2005, 30, 294-324 (i) Gitsov, I.; Lin, C. Curr. Org. Chem. 2005, 9, 1025-1051. (j) Lee, C. C.; MacKay, J. A.; Fréchet, J. M. J.; Szoka, F. C. Nat. Biotechnol. 2005, 23, 1517-1526

(9) For selected examples of mechanically interlocked dendrimers, see: (a) Amabilino, D. B.; Ashton, P. R.; Balzani, V.; Brown, C. L.; Credi, A.; Fréchet, J. M. J.; Leon, J. W.; Raymo, F. M.; Spencer, N.; Stoddart, J. F.; Venturi, M. J. Am. Chem. Soc. 1996, 118, 12012-12020. (b) Yamaguchi, N.; Hamilton, L. M.; Gibson, H. W. Angew. Chem., Int. Ed. 1998, 37, 3275-3279. (c) Hübner, G.; Nachtsheim, G.; Li, Q. Y.; Seel, C.; Vögtle, F. Angew. Chem., Int. Ed. 2000, 39, 1269-1272. (d) Gibson, H. W.; Hamilton, L.; Yamaguchi, N. Polym. Adv. Technol. 2000, 11, 791-797. (e) Osswald, F.; Vogel, E.; Safarowsky, O.; Schwanke, F.; Vögtle, F. Adv. Synth. Catal. 2001, 343, 303-309. (f) Gibson, H. W.; Yamaguchi, N.; Hamilton, L. M.; Jones, J. W. J. Am. Chem. Soc. 2002, 124, 4653-4665. (g) Jones, J. W.; Bryant, W. S.; Bosman, A. W.; Janssen, R. A. J.; Meijer, E. W.; Gibson, H. W. J. Org. Chem. 2003, 68, 2385-2389. (h) Jeong, K. S.; Park, E. J. J. Org. Chem. 2004, 69, 2618-2621. (i) Broeren, M. A. C.; Linhardt, J. G.; Malda, H.; De Waal, B. F. M.; Versteegen, R. M.; Meijer, J. T.; Lowik, D. W. P. M.; Van Hest, J. C. M.; Van Genderen, M. H.; Meijer, E. W. J. Polym. Sci., Part A: Polym. Chem. 2005, 43, 6431-6437.

(10) Aricó, F.; Badjic, J. D.; Cantrill, S. J.; Flood, A. M.; Leung, K. C.-F.; Liu, Y.; Stoddart, J. F. Top. Curr. Chem. 2005, 249, 203-259.

(11) Elizarov, A. M.; Chiu, S.-H.; Glink, P. T.; Stoddart, J. F. Org. Lett. 2002, 4, 679-682.

(12) Elizarov, A. M.; Chang, T.; Chiu, S.-H.; Stoddart, J. F. Org. Lett. 2002, 4, 3565-3568.

(13) Leung, K. C.-F.; Aricó, F.; Cantrill, S. J.; Stoddart, J. F. J. Am. Chem. Soc. 2005, 127, 5808-5810.

(14) (a) Percec, V.; Ahn, C.-H.; Ungar, G.; Yeardley, D. J. P.; Möller, M.; Sheiko, S. S. Nature 1998, 391, 161-164. (b) Percec, V.; Glodde, M.; Bera, T. K.; Miura, Y.; Shiyanovskaya, I.; Singer, K. D.; Balagurusamy, V. S. K.; Heiney, P. A.; Schnell, I.; Rapp, A.; Spiess, H.-W.; Hudsonk, S. D.; Duank, H. Nature 2002, 419, 384-387. (c) Percec, V.; Dulcey, A. E.; Balagurusamy, V. S. K.; Miura, Y.; Smidrkal, J.; Peterca, M.; Nummelin, S.; Edlund, U.; Hudson, S. D.; Heiney, P. A.; Duan, H.; Magonov, S. N.; Vinogradov, S. A. Nature 2004, 430, 764-768. (d) Stephanopoulos, N.: Solis, E. O. P.; Stephanopoulos, G. AIChE J. 2005, 51, 1858-1869.

(15) (a) Brady, P. A.; Sanders, J. K. M. J. Chem. Soc., Perkin Trans. 1 1997, 3237-3253. (b) Rowan, S. J.; Sanders, J. K. M. J. Org. Chem. 1998, 63, 1536-1546. (c) Calama, M. C.; Hulst, R.; Fokkens, R.; Nibbering, N. M. M.; Timmerman, P.; Reinhoudt, D. N. Chem. Commun. 1998, 1021-1022. (d) Newkome, G. R.; Childs, B. J.; Rourk, M. J.; Baker, G. R.; Moorefield, C. N. Biotechnol. Bioeng., Combinatorial Chem. 1999, 61, 243-253. (e) Kaiser, G.; Sanders, J. K. M. Chem. Commun. 2000, 1763-1764. (f) Lukeman, P. S.; Sanders,
J. K. M. Tetrahedron Lett. 2000, 41, 10171-10174. (g) Furusho, Y.; Hasegawa, T.; Tsuboi, A.; Kihana, N.; Takata, T. Chem. Lett. 2000, 18-19. (h) Ramström, O.; Lehn, L.-M. ChemBioChem 2000, 1, 4148. (i) Oku, T.; Furusho, T.; Takata, T. J. Polym. Sci., Part A 2003, 41, 119-123. (j) Brisig, B.; Sanders, J. K. M.; Otto, S. Angew. Chem., Int. Ed. 2003, 42, 1270-1273.

(16) Krämer, R.; Lehn, J.-M.; Marquis-Rigault, A. Proc. Natl. Acad. Sci. U.S.A. 1993, 90, 5394-5398.

(17) (a) Glink, P. T.; Schiavo, C.; Stoddart, J. F. Chem. Commun. 1996 1483-1490. (b) Fyfe, M. C. T.; Stoddart, J. F. Adv. Supramol. Chem. 1999, 5, 1-53. (c) Hubin, T. J.; Kolchinski, A. G.; Vance, A. L.; Busch, D. H. Adv. Supramol. Chem. 1999, 5, 237-357. (d) Hubin, T. J.; Busch, D. H. Coor. Chem. Rev. 2000, 200-202, 5-52. (e) Cantrill, S. J.; Pease, A. R.; Stoddart, J. F. J. Chem. Soc., Dalton Trans. 2000, 3715-3734.

(18) (a) Ashton, P. R.; Campbell, P. J.; Chrystal, E. J. T.; Glink, P. T.; Menzer, S.; Philp, D.; Spencer, N.; Stoddart, J. F.; Tasker, P. A.; Williams, D. J. Angew. Chem., Int. Ed. Engl. 1995, 34, 1865-1869. (b) Ashton, P. R.; Campbell, P. J.; Chrystal, E. J. T.; Glink, P. T.; Menzer, S.; Schiavo, C.; Stoddart, J. F.; Tasker, P. A.; Williams, D J. Angew. Chem., Int. Ed. Engl. 1995, 34, 1869-1871. (c) Kolchinski, A. G.; Busch, D. H.; Alcock, N. W. J. Chem. Soc., Chem. Commun. 1995, 1289-1291. (d) Kolchinski, A. G.; Alcock, N. W.; Roesner, R. A.; Busch, D. H. Chem. Commun. 1998, 1437-1438. (e) Clifford, T.; Abushamleh, A.; Busch, D. H. Proc. Natl. Acad. Sci. U.S.A. 2002, 99, 4830-4836. (f) Chiu, S.-H.; Liao, K. S.; Su, J. K. Tetrahedron Lett. 2004, 45, 213-216. (g) Hung, W. C.; Liao, K. S.; Liu, Y. H.; Peng, S. M.; Chiu, S.-H. Org. Lett. 2004, 6, 4183-4186. (h) Cheng, P. N.; Hung, W. C.; Chiu, S.-H. Tetrahedron Lett. 2005, 46, 42394242.

(19) Schenning, A. P. H. J.; Arndt, J.-D.; Ito, M.; Stoddart, A.; Schreiber, M.; Siemsen, P.; Martin, R. E.; Boudon, C.; Gisselbrecht, J.-P.; Gross, M.; Gramlich, V.; Diederich, F. Helv. Chim. Acta 2001, 84, 296334.

(20) Nakatsuji, Y.; Bradshaw, J. S.; Tse, P.-K.; Arena, G.; Wilson, B. E.; Dalley, N. K.; Izatt, R. M. J. Chem. Soc., Chem. Commun. 1985, 749751.

(21) Since the ${ }^{1} \mathrm{H}$ NMR spectrum of the equilibrium mixture is very complicated, we employed ESI-MS for the characterization of the dynamic combinatorial library. Preliminary gel permeation chromatographic (GPC) analysis (column, American Polymer Standard AM GPC Gel (1) $500 \AA 10 \mu \mathrm{m}$, (2) linear $10 \mu \mathrm{m}$, and (3) linear $10 \mu \mathrm{m}$ columns in series; eluent, anhydrous tetrahydrofuran; temperature, 298 $\mathrm{K}$; flow rate, $1.0 \mathrm{~mL} / \mathrm{min}$; detectors, Wyatt Optilab rEX differential refractometer (wavelength $=685 \mathrm{~nm}$ ) and a Wyatt Tri-Star miniDAWN three-angle light scattering detector (wavelength $=690 \mathrm{~nm}$ ); sample filtration, Millipore PTFE membrane filter (pore size $=0.2 \mu \mathrm{m}$ ); calibration, polystyrene standards) was performed for the equilibrium mixture. The chromatogram of the mixture revealed two signals with the relative molecular weights corresponded to $\mathbf{4 a}-\mathrm{H}_{3} \cdot 3 \mathrm{PF}_{6}$ and $\mathbf{4 c}$ $\mathrm{H}_{3} \cdot 3 \mathrm{PF}_{6}$, plus one broad signal having the relative molecular weight between $\mathbf{4 a}-\mathrm{H}_{3} \cdot 3 \mathrm{PF}_{6}$ and $\mathbf{4} \mathbf{c}-\mathrm{H}_{3} \cdot 3 \mathrm{PF}_{6}$, which attests to the presence of the new, mixed-dendron $[\mathrm{G} 0] /[\mathrm{G} 0] /[\mathrm{G} 2]$ and $[\mathrm{G} 0] /[\mathrm{G} 2] /[\mathrm{G} 2]$ dendrimers. On the other hand, for the mixture of degraded dendrimers after the reduction of [G3]-dynamic dendrimers $\mathbf{4} \mathbf{d}-\mathrm{H}_{3} \cdot 3 \mathrm{PF}_{6}$, the GPC analysis revealed only one broad, overlapped signal (see Supporting Information).

(22) Other unknown signals from the dynamic combinatorial library were observed by ESI-MS having relatively low intensities $(<15 \%)$.

MA061707U 